\title{
Psychological Antecedents of Refugee Integration (PARI)
}

\author{
Gerald Echterhoff Jens H. Hellmann \\ Mitja D. Back Joscha Kärtner \\ Nexhmedin Morina Guido Hertel \\ University of Münster
}

in press, Perspectives on Psychological Science

This is an unedited manuscript accepted for publication at Perspectives on Psychological

Science. The manuscript will undergo copyediting, typesetting, and review of resulting proof before it is published in its final form.

This research was generously supported by a science synergy grant from the Department of Psychology at the University of Münster.

Correspondence should be addressed to Gerald Echterhoff, Social Psychology, Department of Psychology, Westfälische Wilhelms-Universität Münster, Fliednerstr. 21, D48149 Münster, Germany; e-mail: g.echterhoff@uni-muenster.de. 


\section{Highlights}

- We propose a novel model of Psychological Antecedents of Refugee Integration (PARI).

- Perceived forcedness of migration and associated perils are considered as distinctive factors of refugee as compared to non-refugee migration.

- These factors shape integration-relevant psychological responses by refugees and residents to immigration demands.

- We propose psychological mechanisms underlying these effects, for example, refugees' control loss, and residents' perceptions of refugees' privation.

- Implications for occupational work, education, and mental health are described. 


\begin{abstract}
The successful management of refugee immigration, including refugee integration in host societies, requires a sound understanding of underlying psychological processes. We propose a model of the Psychological Antecedents of Refugee Integration (PARI), highlighting perceived forcedness (i.e., coercion and loss of control from "push" factors) and ensuing perils (risks and potential suffering during migration) as distinctive factors of refugee (vs. voluntary) migration. According to our model, perceptions and subjective representations of forcedness and associated perils activate specific psychological processes relevant to refugee integration and thus moderate responses to the demands and stressor of the immigration situation. We conceptualize these distinctive influences for integration-relevant processes in both refugees and in residents. By pinpointing the unique features of refugee migration, PARI generates novel and specific hypotheses about psychological processes predicting refugee integration. For instance, refugees' memories of forcedness and associated perils should lead to high preoccupation with the restoration of basic needs after arrival in a receiving country, which interferes with integration-related activities. Conversely, residents' perceptions of forcedness and related perils may enhance empathy with refugees, but may also magnify feelings of anxiety and threat. Implications for refugee integration are discussed for the domains of occupational work, education, and mental health.

[198 words]
\end{abstract}

Keywords: refugees, forced migration, receiving society, integration, intergroup processes, stress, basic needs 


\section{Psychological Antecedents of Refugee Integration (PARI)}

The world has been grappling with "the largest refugee crisis since the Second World War" (Bansak, Hainmueller, \& Hangartner, 2016, p. 217), which poses significant and urgent challenges for societies, governments, and individuals. By the end of 2017, there were more than 71 million persons of concern for the United Nations High Commissioner of Refugees (UNHCR, 2018a). Even under optimistic projections, forced displacement and large refugee numbers are likely to remain issues in the foreseeable future (International Organization for Migration, 2009; UNHCR, 2018a). We are thus left with the challenge of how to handle the long-term presence of many refugees in host societies. Public debates about refugee-related policies are salient in national and international politics, influence election campaigns and often divide host societies. For reasons elaborated below, we treat integration of refugees as one of the most practical and desirable responses to this challenge (Ager \& Strang, 2008; Doná \& Berry, 1999; Kuhlman, 1991; Strang \& Ager, 2010; also see Deaux \& Verkuyten, 2014). ${ }^{1}$

In general, migrants' wellbeing within the receiving country as well as their inclusion and participation in the receiving society depend on their own and the residents' psychological responses to the demands, stressors, and challenges of migration. However, how does being forced to migrate add to or qualify such demands, stressors, and challenges? In this paper, we introduce a theoretical model for analyzing the ways in which key features of refugee

\footnotetext{
${ }^{1}$ We are aware that a focus on integration as the key outcome can be debated from a critical, political, or normative perspective (e.g., Rudmin, 2003; Rudmin \& Ahmadzadeh, 2001; also see Berry, 2009), and that integration does not satisfy the desires, needs, and hopes of all refugees. However, as important as it is, this debate is not the focus of the present paper. Rather than promoting political arguments for integration, the present paper aims at providing an analysis of psychological processes that are relevant if integration is pursued as a goal of refugee-immigration policies.
} 
migration, that is, forcedness of migration and associated perils, affect these responses. We argue that being coerced to leave the home country is the core characteristic of refugees' experiences as compared to other forms of migration (Ager, 1999; Arnetz, Rofa, Arnetz, Ventimiglia, \& Jamil, 2013; Aron, 1992; Brannan et al., 2016). The distinction between refugee and other, non-forced forms of migration has been widely recognized. For instance, the UN distinguishes between the Global Compact for Safe, Orderly, and Regular Migration and the Global Compact on Refugees (UNHCR, 2018b; United Nations General Assembly, 2018).

The goals of the model introduced in this paper are to provide a refugee-specific conceptualization of integration-relevant psychological processes, and to generate explanations and predictions of integration outcomes for both refugees and host-society residents. Therefore, the current paper provides three main contributions to the literature: First, we address key characteristics that distinguish refugee migration from other forms of migration. Second, we articulate integration-relevant psychological consequences resulting from these characteristics in both refugees and host-society residents. Finally, based on the proposed model we derive potential implications for refugee integration in the fields of occupational work, education, and mental health. In so doing, we focus on how perceptions or subjective representations of forcedness and related perils in the post-migration phase, that is, after arrival in the receiving country, impact integration-relevant psychological processes (e.g., emotions, attitudes, expectations, coping processes) in this phase.

\section{Refugees and the Need for Integration}

Definitions of the refugee status are complex, debated, and vary across countries (Betts \& Collier, 2017; James, 2014; Schönwälder, 1999). The issue is further complicated by the growing diversity of individuals subsumed under the label of "refugee" (FitzGerald \& Arar, 2018; Ludwig, 2016; Shacknove, 1985; Zetter, 2007), which is partly rooted in differences 
among ideological agendas and identity politics. Legal and political considerations are clearly important but they are often silent about the individual experiences of refugees and hostcountry residents. The present paper offers a genuinely psychological approach, driven by the recognition that refugee migration is characterized by high levels of forcedness and associated perils. Consistent with this approach, we focus on how perceived forcedness and associated perils affect integration-relevant responses rather than on legal or political criteria of granting refugee status.

One implication of this psychological definition is that the distinction between refugee and non-refugee migration is continuous rather than categorical, affording a more differentiated analysis of relevant psychological processes. Nevertheless, migrants who are not officially regarded as refugees but rather labeled as "economic migrants" or "fortune seekers" in public discourse may feel that they were forced to leave their homes due to a lack of employment perspectives that are vital for their survival (Kotzur, Forsbach, \& Wagner, 2017; Richmond, 1993; Verkuyten, 2004; for a media example, see Reid, 2016). Thus, our psychological analysis covers degrees of perceived forcedness regardless of whether migrants fall into a legally or politically defined category of "refugee."

We consider integration as a key goal of refugee-immigration management (Chimni, 2004; Esses, Hamilton, \& Gaucher, 2017; Marchi, 2005). In the present paper, integration is understood as an interactively achieved, multilevel process aimed at a desirable outcome (Bourhis, Moïse, Perreault, \& Senécal, 1997), that is, increasing participation and inclusion of groups or people who are initially distant and excluded from a dominant society (Ager \& Strang, 2008; Marchi, 2005; Strang \& Ager, 2010). This interactive-procedural view is consistent with common definitions, for instance, the view that integration is "a process through which newcomers become capable of participating in the economic, social, and civic/political life of the receiving country" (Seidle \& Joppke, 2012, p. 9). Notably, our 
understanding of integration differs from a common view in acculturation research, which considers integration primarily as immigrants' orientation towards both maintenance of their heritage culture and engagement with the host culture (Berry, 1980, 2003). In contrast, our conceptualization allows us to analyze how a desirable process with a defined outcome (i.e., refugee integration) is affected by both refugees' and residents' psychological responses to the immigration situation.

Thus understood, the main criteria of integration concern refugees' participation and inclusion in the receiving society in the domains of occupational work, economy, education, and health (Ager \& Strang, 2008; Odé \& Veenman, 2003). The feasibility of integration in these domains requires a sufficient level of structural-economic development in a receiving country (Kuhlman, 1991). In other words, integration is more feasible in countries with higher (vs. lower) development in the work, education, and health sectors. Thus, we acknowledge that the present model is more applicable to refugees in wealthier countries (e.g., Northern America, EU countries, or Australia and New Zealand) than in disadvantaged, poorer countries (e.g., Bangladesh or Sudan).

The majority of refugees are unlikely to return home (UNHCR, 2018c). Whereas extradition or forced repatriation rank high on some political agendas, these measures are ethically questionable to the extent that they expose refugees to substantial risks and may violate human rights and international conventions (Gostin \& Roberts, 2015). In addition, extradition and forced repatriation face practical and logistic limitations (Chimni, 2004; Essuman-Johnson, 2011). Concerning acculturation orientations, psychological and social outcomes are typically better when immigrants pursue bi-cultural integration rather than when they focus primarily on preserving their own cultural traditions (Nguyen \& Benet-Martínez, 2013; Sam \& Berry, 2010; Zagefka \& Brown, 2002). For these reasons, we focus on 
integration as a key goal of managing the presence of refugees in countries with a sufficient level of structural and economic resources.

This being said, it is clear that the current "refugee crisis" would ideally be resolved best by eliminating "push" factors such as violent conflict or persecution, and by improving living conditions in the countries of origin. However, the political and economic conditions in refugees' home countries are often intractable and unlikely to improve in the near future (e.g., Barnard \& Saad, 2018). Thus, refugees as well as hosting societies are in need for scientifically grounded concepts and guidelines for managing refugee immigration, including the important goal of refugee integration.

\section{Structure and Rationale of the PARI Model}

Existing models of immigration and acculturation focus on stressors from the immigration situation and (affective, cognitive) responses that are involved in the coping process (Berry, 2005; Doná \& Berry, 1999; Ward \& Geeraert, 2016; Yakushko, 2010; for a review, see Kuo, 2014). As such, these models have been useful and productive for analyzing challenges and barriers of immigrants' adjustment to the new living conditions. However, these models only rarely consider specific challenges that result when persons are forced to migrate instead of changing their place of living voluntarily. Differences between voluntary migrants and refugees have been discussed in the literature (e.g., Berry, Kim, Minde, \& Mok, 1987; Murray \& Marx, 2013), for instance, in terms of refugees' vulnerability (Allen, Vaage, \& Hauff, 2006; Berry et al., 1987; Liebkind, 1996). However, distinct features of refugee migration relative to migration in general have not figured prominently in these discussions. What is missing is a conceptual analysis of the implications of such differences for refugee integration and the underlying psychological processes. A sound understanding of these implications is desirable not only for epistemic reasons but also to provide practical guidance for policy makers and intervention planers. The proposed model on the Psychological 
Antecedents of Refugee Integration (PARI, see Figure 1) fills this gap by addressing distinctive characteristics of refugee migration (specifically, forcedness of migration and related perils), and by articulating integration-relevant psychological processes triggered by these unique characteristics.

Similar to the integration of immigrants more generally, refugee integration depends on refugees' and residents' psychological responses to the immigration situation. Thus, the PARI model recognizes the fact that migrant integration depends on both groups. This approach resonates with existing models of acculturation that have recognized the importance of a dual perspective that considers responses by both acculturating minority members and majority members (Bourhis et al., 1997; Berry, 2005; Haugen \& Kunst, 2017; Sam \& Berry, 2010; Ward \& Geeraert, 2016). Going beyond these existing models, however, the PARI model conceptualizes how responses of both refugees and residents are affected by perceptions and subjective representations of forcedness and related perils.

\section{The Central Feature of Refugee Migration: Forcedness}

We regard forcedness as the central defining feature of refugee migration. This view is consistent with a crucial aspect of the current UNHCR definition of a refugee, that is, "a person forced [emphasis added] to flee their country because of violence or persecution" (UNHCR, 2019). In a general sense, forcedness means that a person's behavior is driven or coerced by external factors. There are various external factors (e.g., persecution, violence, or economic crises) that force people to emigrate. For instance, politically rooted violence (genocide or civil war) and ethnic rebellions have been found to predict forced migration (e.g., FitzGerald \& Arar, 2018; Moore \& Shellman, 2004; Schmeidl, 1997; cf. Neumayer, 2005). 
These external push factors need to be distinguished from subsequent, post-arrival perceptions or representations of forcedness. ${ }^{2}$

Two key implications of our rationale are noteworthy. First, as noted above, refugee migration is defined by subjective psychological states (current representations or perceptions), rather than by objective features of external conditions. Of course, the subjective experience of forcedness stems from objective violence and perils. However, we focus on the impact of subjective representations of forcedness on integration-relevant psychological processes. This psychological perspective has both ethical and practical implications: It is the post-migration perception of forcedness that (1) defines refugees' and residents' psychological reality of immigration, (2) triggers integration-relevant responses of refugees and residents, and (3) should be considered in designing refugee-integration interventions.

Second, migrants can vary continuously in how much they perceive themselves as being forced. Also, others can vary in the extent to which they see migrants as being forced. Residents have different lay concepts of refugees, and these concepts can be more or less elaborate and more or less consistent with political or legal definitions (Betts, 2010; Shacknove, 1985; Zetter, 2007). According to our model, residents perceive migrants to a greater extent as "genuine refugees" the more they assume that migrants were forced to leave their homes under perilous circumstances. By recognizing the variability of perceived

\footnotetext{
${ }^{2}$ Our model addresses integration processes emerging after arrival in the receiving country. Thus, our analysis of distinctive effects of forcedness considers (refugees' and residents') post-migration perceptions of forcedness rather than actual, pre-migration forcedness. Pre-migration forcedness is rooted in push factors in the home country, which triggered refugees' emigration from their home country. However, terms such as "perception of forcedness" or "perceived forcedness" should not be misunderstood as implying that these perceptions are mere imaginations or disconnected from objective perils or push factors of migration.
} 
forcedness, our approach allows us to distinguish refugee migration from other forms of migration on a continuous rather than dichotomous scale.

\section{Perils, Risks and Suffering associated with Forced Migration}

Being forced to leave the home country is associated with perils, risks, and suffering before and during migration. Thus, forcedness is rooted in severe pre-migration perils such as violent conflict and persecution but also poverty, lack of employment, or adverse environmental conditions (some resulting from climate change). The relation between forcedness and pre-migration perils is succinctly captured by a quotation from a Syrian refugee, now residing in Germany: "To stay is equivalent to suicide (Bleiben bedeutet Selbstmord).” (Amjahid, 2015, p. 100). Pre-migration perils can have considerable psychological effects which potentially emerge for all people in the afflicted regions (Morina, Stam, Pollet, \& Priebe, 2018; Priebe, Giacco, \& El-Nagib, 2016), not only those who migrate (see Carlsson \& Sonne, 2018). Thus, perils present in the homeland alone do not exclusively affect refugees. However, pre-migration perils are an essential part of the refugee experience and residents' views of refugees, and are much more likely to emerge for forced (vs. voluntary) migrants. Therefore, we do consider effects of these perils on refugees' and residents' integration-relevant responses to immigration in our model.

The forced and often abrupt nature of refugee migration increases the likelihood of experiencing (or taking the risk of) perils during the migration process itself (migration perils). Being forced to leave the home country restricts opportunities for proper planning of migration, and enhances the acceptance of high-risk situations during the migration journey. These risks include placing oneself at the mercy of smugglers, traffickers (Morrison \& Crosland, 2000), or foreign authorities (Harrell-Bond, 1999), and attempting to cross state borders without entry permissions or visas. A vivid account of these perils is provided by Gulwali Passarlay (2015), for instance: “One of the strangest things about this journey was 
how whenever a smuggler or a driver gave us an instruction, we simply followed it. (...) Without questioning or really even thinking, we put our lives into the hands of strangers, time and again. We had no choice."

Consistent with our focus on integration in the receiving society, we consider the impact of pre-migration and migration perils on psychological processes in the post-arrival, immigration situation. For refugees, these perils are, for instance, represented in their cognitive representations (memories) and current feelings about emigration and the migration journey. For residents, the perception of migrants' forcedness is connected to perceptions, assumptions, or ideas about pre-migration "push" factors and about migration perils, such as physical abuse or shipwreck during the migration journey. We note that forced migrants can also face perils and risks after arrival in a receiving country, that is, in the post-migration stage (e.g., Syrian refugees in Turkey; Human Rights Watch, 2019). Within the structure of the PARI model, such post-migration perils are treated as stressors emerging in a receiving country.

\section{Psychological Processes Relevant to Refugee Integration}

Our model considers how refugees' and residents' integration-relevant psychological processes and immigration-driven responses (middle right box in Figure 1) are shaped by current perceptions and representations of forcedness and related perils. These perceptions can affect psychological processes directly (path $c$ in Figure 1) or moderate effects of immigration-related demands and stressors on psychological processes (path $b$ in Figure 1). Psychological processes are integration-relevant to the extent that they can theoretically predict integration-relevant outcomes (depicted by path $d$ in Figure 1). As discussed above, the main criteria for integration are inclusion and participation in key domains such as work, education, and health (right box in Figure 1). Integration-relevant processes include coping with stressors and threats to basic needs (meaning, belonging, control), evaluations of the 
receiving society and its residents, goal setting (getting education or employment, staying or leaving the receiving society), motivation for cultural learning, anticipations and expectations of critical future events (success of goal attainment), and related behavioral intentions. Among these responses, we focus on those that can plausibly be moderated by perceived forcedness and related perils. We argue that this focus provides novel perspectives on the explanation and prediction of refugee adjustment and integration.

To enhance the explanatory depth of our model, we also propose psychological mechanisms, or mediators, that underlie the moderating effects of perceptions of forcedness and related perils and related perils (dashed paths $m_{1}$ and $m_{2}$ in Figure 1). We argue, for example, that the effects of perceived forcedness on migrants' motivation to learn and to adapt to the new environment is psychologically mediated by experienced loss of control. In this case, perceived forcedness induces perceived control loss (dashed path $m_{1}$ ), which in turn moderates the effects of post-arrival immigration stressors on learning motivation (dashed path $m_{2}$ ). We note that, at this juncture, our model is designed to encourage researchers to consider specific psychological mediators of forcedness effects rather than to yield specific hypotheses about the relative strength of the direct moderation effect (i.e., path $b$ ) and the indirect effect via psychological mediators (i.e., via the dashed paths $m_{1}$ and $m_{2}$ ), or the type of mediation (full vs. partial).

The PARI model also accommodates context and person factors (bottom and top boxes in Figure 1). Context factors include the salience of refugee-related information in the media and public discourse, socioeconomic, cultural, and political conditions as well as more specific, local social environments refugees and residents are situated in (e.g., Wehrle, Kira, \& Klehe, 2019). Person factors include individual differences such as basic personality traits, social and cultural identity, sociodemographic attributes, and socioeconomic characteristics. Migrants' personality traits are particularly relevant to our model to the extent that they can 
serve as individual resources for coping with immigration. These resources include a person's resilience, including extraversion, agreeableness, openness, emotional stability, generalized trust, level of education, (cultural) intelligence, motivational persistence, wisdom (including conflict resolution skills or perspective taking), orientation towards collectivism, and religiosity (see Cobb et al., 2019; Sleijpen, Boeije, Kleber, \& Mooren, 2015; Ward \& Geeraert, 2016). For instance, more extraverted migrants are more likely to reach out and network with residents, whereas other, more introverted migrants remain isolated. These differences are epitomized by the reports of two refugees in Luxemburg (Mestheneos \& Ioannidi, 2002, p. 317). A young Iraqi man said: "When you live in such a society you feel isolated. More than that, relations with neighbors are virtually non-existent. I have no idea what my neighbors are like." In contrast, a Peruvian refugee remembers how he found support from the local parish: "I made the acquaintance of the parish priest and it was him who offered me work. I had never been unemployed. As soon as I got my status the next day I started working."

We propose that the effects of person and context factors be conceptualized in a multilevel and dynamic transactional way (for an example, see Christ et al., 2014). Specific integration-relevant experiences and behaviors of refugees and residents are simultaneously nested within individual actors and individual partners both of which are nested within contexts. Furthermore, actor and partner person factors as well as context factors not only shape integration-relevant processes, but they can also be shaped and influence each other via these processes (for an example, see Back et al., 2011). Next, we describe the PARI model in more detail, first from the perspective of refugees, and then from the perspective of hostsociety residents. 


\section{How Perceived Forcedness and Related Perils Affect Responses to Post-Arrival Demands: The Perspective of Refugees}

The structure of the PARI model echoes established accounts of how individuals respond to novel and stressful environmental conditions, leading to more or less successful adjustment to altered living conditions or major life changes (Gross, 1998; Lazarus \& Folkman, 1984). Indeed, immigration in general is connected with various demands and stressors, including unfamiliar immigration procedures, subjection to foreign authorities, laws and regulations, restricted freedom of movement, confrontation with divergent cultural norms and habits, language barriers, loss of familiar environmental structures and social contexts, unemployment, loss of social status, xenophobia, and discrimination (e.g., Castro \& Murray, 2010; Kuo, 2014; Yakushko, 2010; also see Fozdar \& Torezani, 2008). Such demands and stressors in the post-migration phase, that is, after arrival in the receiving country, trigger specific psychological responses in the PARI model (path $a$ in Figure 1).

A key response to demands and stressors after arrival in the receiving country is the experience of threats to fundamental needs (Ward, Bochner, \& Furnham, 2001), such as need for mastery and control, self-esteem and enhancement needs, belonging and connectedness needs, and the need for meaning, understanding and prediction of future events (Deci \& Ryan, 2000; Fiske, Rosenblum, \& Travis, 2004; Higgins, 2012; Hogan \& Blickle, 2018; Smith, Mackie, \& Claypool, 2014). These threats can cause various emotional problems, including anxiety (Bronstein \& Montgomery 2011; Fazel, Reed, Panter-Brick, \& Stein, 2012; Lustig et al., 2004), feelings of loneliness and isolation (Gorst-Unsworth \& Goldenberg, 1998; Miller et al., 2002), loss of control and experiences of powerlessness (Li, Lidell, \& Nickerson, 2016), impediments to motivation and goal pursuit (Yakushko, Watson, \& Thompson, 2008), disillusionment (Vrecer, 2000), and, generally, acculturative stress and subsequent coping 
attempts (Berry, 1997; Castro, \& Murray, 2010; Flaskerud \& Uman, 1996; Ward \& Geeraert, 2016; Yakushko, 2010).

Perceptions and memories of forcedness and related perils can affect such psychological responses directly (path $c$ in Figure 1). For instance, profound forcedness threatens individuals' need for control, and thus might elicit attempts at regaining a sense of control. While such effects emerge regardless of arrival in a receiving society, there is another class of processes that are specific to the post-arrival situation of immigration. These latter processes refer to how perceived forcedness and related perils can moderate effects of immigration stressors on integration-relevant psychological processes (path $b$ in Figure 1). Considering such moderation effects is an important way in which our model expands existing models of migration and acculturation. To enhance the precision of our model, we propose psychological mechanisms that might underlie or translate such moderation effects (dashed paths path $m_{1}$ and $m_{2}$ in Figure 1). For example, migrants' loss of control is a psychological consequence of perceived forcedness (dashed path $m_{1}$ ). Low sense of control and self-efficacy, in turn, should increase effects of post-arrival demands and stressor on integration-relevant processes (dashed path $m_{2}$ ), such as effects on individuals' motivation and self-initiative. Thus, perceived control and self-efficacy would be conceptualized as specific psychological mediators underlying the moderating effect of perception of forcedness.

In the following, we discuss how refugees' perceptions of forcedness and migration perils can moderate the effect of immigration demands and stressors on integration-relevant responses. In so doing, we particularly focus on psychological states and processes that are triggered by perceived forcedness, and thus mediate the moderating effects of forcedness on migration-related demands and stressors. Psychologically, we assume that perceived forcedness of migration triggers experiences of loss of control over one's past, current, and future outcomes, lack of choice, external attribution of events, cognitions related to 
inevitability and low personal responsibility (Castles, 2003; Chimni, 2009; Richmond, 1993). Perils related to forced migration should trigger perceptions and memories of suffering (e.g., Pineteh, 2017). Accordingly, our subsequent discussion focuses on loss of control, external attribution, uncertainty about future events, and perceptions and memories of severe suffering and violence. These states and processes are thus treated as proximal psychological mediators of the moderating effects of perceived forcedness on the association between migration demands and integration-relevant responses of individuals (see Figure 1). At the end of each subsection, we discuss how the considered moderation effects might be additionally qualified by person and context factors. Empirical evidence is still scarce, but will be noted whenever available.

\section{Loss of Control}

Being forced to migrate involves experiences of lacking or losing control. Having little or no command over vital circumstances and events of one's life (e.g., place of residence, abandoning one's property or job) threatens fundamental needs for mastery, agency, and control (Taylor, 1983; Ward et al., 2001). These threats trigger attempts directed at restoring need fulfillment (Sleijpen et al., 2015), which is likely to moderate migrants' responses to post-arrival demands and stressors. Specifically, being preoccupied with need restoration is likely to restrict cognitive resources (Lazarus \& Folkman, 1983; for refugees, see Yakushko et al., 2008) and the mental stamina needed for integration-relevant, self-regulatory activities, such as planning and managing of one's future life in the receiving society and effective intercultural communication (Christmas \& Barker, 2014). Thus, attempts of need restoration should decrease migrants' resources to actively pursue their integration in the receiving society, and distract from adjustment to the new living conditions in the receiving society. These effects should emerge particularly in the initial post-arrival period. 
Furthermore, intense or repeated experiences of losing control can undermine selfefficacy and agency beliefs (Bandura, 1997) and lead to learned helplessness and depression. Indeed, depressive reactions have been observed recurrently in refugees (e.g., Keles, Idsøe, Friborg, Sirin, \& Oppedal, 2017; Liebkind, 1996). A diminished sense of self-efficacy is more likely for refugees as compared to voluntary immigrants in the first months after arrival in the receiving country, and it should increase generalized perceptions of dependency on external factors and erode learning and performance motivation (Zimmerman, 2000). These effects are detrimental to adaptation to demanding new living conditions in general, and to refugee integration in the receiving society in particular. The testimony from an educated Iraqi Kurd living in the Netherlands illustrates these problems: "I have no expectations. I live day by day. I don't care anymore. I wonder why sometimes. Maybe it is because I have become a refugee. I don't feel anything. I just hope for a better future for my children.” (Mestheneos \& Ioannidi, 2002, p. 316).

We further propose that the direction and strength of control-loss effects is additionally qualified by context and person factors. For instance, the restoration of control and mastery needs should be facilitated by context factors such as cultural diversity and pro-immigration norms, or multicultural (vs. assimilationist) orientations of the receiving society (Ward, Gale, Staerklé, \& Stuart, 2018), institutions, and organizations (e.g., companies). Regarding person factors, greater openness to new experiences (McCrae, 1987), motivational persistence (see Schuler, Thornton, Frintrup, \& Mueller-Hanson, 2003), and a lower need for closure (Webster \& Kruglanski, 1994) should be beneficial for finding new ways of meaning-making and for forming new explanatory schemata. This, in turn, might help refugees to regain their challenged sense of mastery, agency, and control.

Research also suggests that migrants with personal dispositions such as enthusiasm, persistence or hope, are better able to find creative or unusual remedies to perceived assaults 
on agency and control (see Cobb et al., 2019). An illustration is the case of Mahmoud Al Fawal, who fled from Syria to Ghana, which is a rare destination for Syrian refugees (Bogner \& Hertzberg, 2019). Mahmoud, an enthusiastic, intelligent and open-minded electronics businessman, intentionally chose Ghana over Europe because he did not want to be a passive recipient of help but act autonomously and set up his own electronics store.

In this respect, we note the, often overlooked, impact of culturally rooted gender roles in such processes. A female Syrian refugee would be unlikely to take the actions taken by Mahmoud. Female refugees are not only exposed to particular perils and threats before and during migration, such as sexual violence, abuse etc. (Krause, 2017). Due to gender differences in expected or permissible agency and competence, they also face additional challenges in (re-)achieving a sense of control and mastery. A creative example of how to tackle these gender-specific challenges is the Migration Blanket, a community project in Birmingham (UK) designed to empower refugee women (Arts Council England, 2019; Iqbal, 2019). Building on a recently emerging political arts movement called craftivism, the activist Salma Zulfiqar encouraged 15 female refugees with distressing experiences of forced migration to jointly stitch a quilt, which has been exhibited at the Venice Biennale. Each woman contributed a hexagonal piece on which she inscribed not only her specific migration experiences but also hopes and aspirations for the future. The project offers opportunities for restoring agency and confidence, using a form of participation with a low threshold for women from the Islamic world.

\section{External Attribution}

The experience of forced migration is likely to diminish the degree to which individuals experience control and a sense of personal responsibility following major life events, with negative consequences for integration-relevant outcomes. However, migrants who attribute their emigration externally (vs. internally) might also be less likely to feel guilt and 
self-blame for distressing migration-related conditions (for a demonstration of the potential mechanism, see Specht, Egloff, \& Schmukle, 2011), such as poor accommodation or loss of socioeconomic status in the receiving country. External attribution of migration also implies a lack of personal responsibility for distressing negative outcomes faced by migrants in the receiving country (Weiner, 2000). Such external attributions of forced migration are, of course, valid. However, the experienced lack of personal responsibility for emigration may attenuate (i.e., moderate) guilt or self-blame responses. Thus, to the extent that the act of migration is externally attributed, stressors experienced in the receiving country are less likely to elicit negative emotions related to self-blame, that is, guilt or shame. Consistent with our analysis, extant research suggests that immigrants' external attribution following experiences of discrimination in the receiving country can have self-protective effects (Liebkind \& Jasinskaja-Lahti, 2000).

Person and context factors can again amplify or weaken these effects. External attribution should be particularly pronounced in refugees with a dispositional external attribution style (external locus of control; Weiner, 2000). An external attribution tendency can amplify negative consequences for integration activities but can also facilitate the selfprotective effects outlined above. Moreover, context factors such as the degree to which the receiving society is individualistic versus collectivistic (Markus \& Kitayama, 1991) might intensify both effects: External attributions should make integration more difficult in a host culture that espouses individual agency and responsibility to a greater (vs. lesser) extent.

\section{Uncertain Future Time Perspective}

For migrants in general, novel and unfamiliar conditions in a receiving society can affect future-directed psychological processes, including goal-setting, motivation, planning, and prediction (e.g., De Vries \& Van Heck, 1994; El-Shaarawi, 2015). When migration is forced (vs. voluntary) and precipitous, opportunities for planning one's journey and preparing 
one's stay or life in the receiving country are restricted. Thus, forcedness of migration amplifies uncertainty about future events and outcomes, for instance, about the length of the stay in the receiving country, and about the prospects of returning home. Such uncertainty is often compounded by immigration regulations and asylum policies for forced (non-regular) migrants in the receiving countries. Refugees usually do not know at the time of their arrival how long they have to, or will be, permitted to stay in a receiving country.

Thus, refugees should feel more uncertain and ambivalent regarding their future place of residence. Such fundamental uncertainty about one's life course is likely to interfere with cognitive and motivational processes that promote adjustment and integration in the receiving country (Ward et al., 2001). For instance, ambivalence and uncertainty about future events are stressors that interfere with one's ability to achieve work-related goals (Reisel, Probst, Chia, Maloles, \& König, 2010; Sverke, Hellgren, \& Näswall, 2002). Moreover, a limited future time perspective can impede learning orientation, social interaction and job-related motivation and behavior (Carstensen, 2006; Zacher \& Frese, 2009). For instance, when their future time perspective in the receiving country is restricted, refugee (vs. non-refugee) migrants might be less interested in time-intense job trainings and more likely to accept unskilled labor, restricting their chances of occupational success and growth in the receiving society (Hertel, Hellmann, \& Echterhoff, 2019). By this account, uncertainty about one's future in the receiving country interferes with long-term investments and full integration in the employment sector. At the same time, however, perceived forcedness and related push factors in the home country might also foster integration efforts by decreasing the perspective to return to the home country. Also, a limited future time perspective induces individuals to glean meaning in life to a greater extent from ongoing positive experiences (Hicks, Trent, Davis, \& King, 2012).

The degree to which these refugee-specific processes are triggered can be influenced by personality characteristics such as optimism, chronic time perspectives, and a motivational 
focus on long-term (vs. short-term) goals. Context factors such as administrative and political constraints or the degree of supportive societal structures in the receiving country can also intensify or mitigate effects of future uncertainty, thereby influencing integration outcomes. Effects of perceived forcedness on future time perspective might, for instance, be eliminated, when refugees receive unlimited permits to stay in the receiving country (Cortes, 2004).

Relatedly, a relatively low desire and preparation for a long-term stay in the receiving country (vs. a foreseeable or anticipated return to their home country) restricts the likelihood and chances of eventual integration in the receiving country. Thus, refugees' short-term goal setting regarding their place of residence can be regarded as an integration-relevant process that is affected by perceived pre-migration perils and push factors. If the receiving country offers reasonable prospects for a continued stay, refugees may be more motivated than are voluntary migrants to pursue integration in the receiving society. Indeed, Cortes (2004) found that refugee immigrants in the U.S. were, in the long run, more successful on the job market and earned higher salaries than "economic immigrants." Cortes explained this finding with a longer time horizon of refugees as compared to immigrants, owing to the fact that a return to the home country was not a feasible option.

\section{Perceptions and Memories of Suffering and Violence}

Being forced to leave the home country is usually associated with severe perils and threats both before and during the migration journey. These experiences are also likely to afflict refugees in the post-arrival phase, specifically through persistent memories of traumatic events and fear of deportation. One consequence of these experiences might be approachavoidance conflicts: Many refugees hope to be able to return home soon (Betts \& Collier, 2017), however, due to the adverse conditions in their home country, they also want to stay away. According to our rationale, experiences of threat and suffering should moderate migrants' responses to demands and stressors in the receiving country (path $b$ in Figure 1). On 
the one hand, responses to major stressors in the receiving country may be exacerbated as a result of similar previous experiences of perils. For instance, anxiety in the interaction with host-country authorities might be enhanced in migrants who have been threatened, indoctrinated or even tortured by executive or military staff during migration (Otto \& Hinton, 2006; Silove, Sinnerbrink, Field, Manicavasagar, \& Steel, 1997). In the same vein, restricted freedom of movement in the receiving country may lead to aggravated distress responses by migrants who have encountered distressing conditions in refugee camps (Beiser, Turner, \& Ganesan, 1989) or who have experienced confinement or captivity during their migration journey.

Severely distressing or traumatizing experiences in the home community, such as threats or violence by people from one's immediate environment (Gostin \& Roberts, 2015; Riaño-Alcalá, 2008), may destroy interpersonal trust to a degree that encumbers social interaction and the formation of relationships with members of the receiving society. Such problems would clearly impede activities necessary for integration. A particularly distressing and traumatic experience is loss of significant others (e.g., Frater-Mathieson, 2003). Grief associated with counterfactual ruminations, or feelings of guilt about circumstances of death and one's own role therein may limit the sense of self-efficacy needed for active coping with current needs (Glickman, Shear, \& Wall, 2017). Prolonged grief reactions might interfere with effective psychosocial functioning in new environment (Killikelly, Bauer, \& Maercker, 2018).

On the other hand, migrants who have been exposed to substantial perils before or during migration might be more willing and committed to finding ways of adapting to a new environment, and may respond less negatively to minor stressors (e.g., lack of familiarity with the new environment) due to comparison with high levels of prior distress. Moreover, it is even possible that persons who have managed to cope with severe perils, threats, or suffering are able to turn these experiences into personal growth and strength (Joseph \& Linley, 2005; 
Wehrle, Klehe, Kira, \& Zikic, 2018). For instance, coping with traumatic experiences might, ultimately, entail a sense of mastery and personal strength, a new appreciation of life's possibilities, and warm, intimate relationships — consequences captured by terms like “transformational coping” (Aldwin, 1994), "strength from adversity" (McCrae, 1984), or "posttraumatic growth" (Tedeschi \& Calhoun, 1996). The achievement of maturity and strength from adversity is vividly expressed by one young refugee in a Dutch study by Sleijpen, Mooren, Kleber, and Boeije (2017, p. 354): "Dutch adolescents are like babies: they have experienced nothing and I've seen everything." Thus, it is possible that successful coping with distress from migration experiences helps migrants to approach new opportunities in the long run, seize new ways of meaning-making and new social relations. In a similar vein, migrants' active attempt to disengage from distressing experiences of migration may also enhance their openness to alternative cultural values and ideas, including ideas and norms about childhood education and parenting. Such integration-facilitating responses are more likely to emerge for refugee (vs. non-refugee) migrants.

Again, the direction of such effects (promoting or impeding integration in response to migration stressors) should depend on person and context factors. Person factors that should increase the likelihood of positive effects include high levels of resilience (Bonanno, 2004; Wagnild \& Young, 1993), generalized trust (Oskarsson, Dawes, Johannesson, \& Magnusson, 2012), emotional stability (Brown \& Rosellini, 2011); agreeableness (Freitag \& Bauer, 2016), and interpersonal warmth (Bayes, 1972). It has been argued that refugees' resilience towards distress from traumatic, trust-threatening events is related to internal locus of control, secure attachment style, and high self-esteem (Ahmed, 2007; Sleijpen et al., 2015). The likelihood of integration-impeding effects should be enhanced in migrants with high scores on antagonism (see McCrae \& Costa, 1997) or dark triad traits (see Paulhus \& Williams, 2002). Regarding context factors, positive, integration-promoting effects should be facilitated by communal, 
collectivistic (Abele \& Wojciszke, 2007), and, more specifically, multicultural orientations of the hosting society (Ward et al., 2018). Integration-impeding effects should be more likely when the environment in the receiving society provides more (vs. less) salient cues to rejection and aggression, and when the receiving society culture is generally tight (vs. loose) (Geeraert, Li, Ward, Gelfand, \& Demes, 2019).

\section{Testing the PARI Model for Refugees}

The PARI model proposed in Figure 1 is a theoretical model. We are aware that the statistical examination of predictions derived from the PARI model, particularly of combined effects of moderation and mediation, is not trivial (e.g., Holland, Shore, \& Cortina, 2017). Here, we highlight methodological aspects that should be considered when testing key predictions derived from our model. Demands and stressors of the immigration situation (the main independent variables) as well as refugees' responses to these demands (e.g., motivation, emotion, learning) need to be assessed. Perceived forcedness and/or associated perils would serve as general moderator variables, and one or more of the proposed psychological mechanisms (e.g., control loss, external attribution, suffering) as specific mediators of forcedness effects (dashed paths in Figure 1). If possible, tests of models including both moderation and mediation should employ longitudinal designs (Holland et al., 2017).

Person and context factors can be added regarding main effects on demands and stressor, perceived forcedness, and integration-relevant responses, and as moderators of the associations among them. Analyses including person and context factors need to implement a multilevel design in which individual refugees' responses on Level 1 are nested within contexts on Level 2 (e.g., Christ, Asbrock, Dhont, Pettigrew, \& Wagner, 2013). Such a design allows researchers to simultaneously analyze the effect of person and context variables (and their interactions) on the outlined integration dynamics and associations between immigration 
stressors, forcedness and integration-relevant responses at the individual and the context level, ideally again with longitudinal designs (for an example, see Christ et al., 2014).

The PARI model suggests that perceptions of forcedness and perils ought to be assessed on continuous psychological scales rather than merely assigned based on legal or administrative categories (Erdal \& Oeppen, 2018; van Hear, 1998). Migrants can be asked to report their pre-migration and migration experiences of forcedness with qualitative open questions (coded for the degree of forcedness and associated perils) or with rating items. Given the specific experiences of forced migration and related threats and insecurities, perceived forcedness has to be operationalized in ways that allow migrants to provide valid answers, for instance, with questions regarding "push" and "pull" factors, efforts to leave their home, attitudes and feelings about their migration, or duration of their journey. Social desirability effects need to be considered given that refugees may distrust institutions (including universities), even if anonymity or confidentiality is granted. Immigration-related demands and stressors can be assessed via observation and data collection from migration shelters, immigration staff, and responsible authorities in the receiving country. Main dependent measures are integration-relevant responses, such as attitudes toward the receiving society and integration, acculturation preferences, control beliefs, attribution style, anxiety, uncertainty, future time perspective, and integration outcomes in the domains of work, education, societal and civic participation, and mental health.

\section{How Perceived Forcedness and Related Perils Affect Responses to Post-Arrival}

\section{Demands: The Perspective of Residents of the Receiving Society}

We now describe the PARI model from the perspective of residents of the receiving society, again beginning with the demands and stressors related to the immigrant situation (see Figure 1). For residents, these demands and stressors include the fear of losing one's ethnic, cultural and religious identity, real or imagined contact with strangers who might not be 
appreciative of the receiving society's cultural values and customs, exposure to unexpected or uncontrollable events, real or imagined exposure to ill, traumatized, or aggressive individuals, confrontation with cultural and religious differences, and competition for resources such as government services, social support systems, or housing (Esses et al., 2017; Schweitzer, Perkoulidis, Krome, Ludlow, \& Ryan, 2005). Residents' responses to immigration demands identified in the extant literature include (acculturative) stress (Berry, 1997; Castro, \& Murray, 2010; Flaskerud \& Uman, 1996; Yakushko, 2010), perceived threat (Esses et al., 2017; Stephan, Ybarra, \& Bachman, 1999; Ward \& Masgoret, 2006), anxiety (Gudykunst, 1995; Stephan \& Stephan, 1992; Ward \& Masgoret, 2006), and uncertainty (Gudykunst, 1995), but also recognizing the stressors and adverse conditions faced by immigrants and corresponding intentions to help (Stürmer \& Siem, 2017).

Analogous to the rationale for refugees, we focus on residents' responses (e.g., empathy, perceived threat, attitudes toward refugees) that are (a) integration-relevant and (b) potentially susceptible to moderation by perceived forcedness and related perils. As for migrants, the association between demands and stressors, on the one hand, and residents' responses is depicted by path $a$ in Figure 1. As for migrants, residents' perceptions of migrants' forcedness and associated perils may have main effects on their psychological responses, that is, effects that emerge irrespective of demands from a given immigration situation (path $c$ in Figure 1). For instance, learning about severe suffering or violence of migrants during their migration journey may elicit compassion or even feelings of shock among perceivers around the globe, regardless of the immigration situation in their own country (Moeller, 1999; Tascón, 2003). Importantly, however, perceptions of forcedness and associated perils are also assumed to moderate residents' integration-relevant responses to immigration (path $b$ in Figure 1). Again, we argue that the direction and strength of these effects may additionally be qualified by person and context factors. In the following, we 
develop a rationale and hypotheses on how perceived forcedness of migration and related perils affect residents' integration-relevant psychological responses to the immigration situation. In so doing, we specify the psychological mechanisms or mediators underlying the proposed effects of forcedness and peril perceptions (dashed paths $m_{1}$ and $m_{2}$ in Figure 1).

\section{Perceptions of Refugees' Future Time Perspective and Interest in the Receiving society}

Residents' perception of refugees' forcedness might induce the feeling that refugees lack intrinsic interest in the receiving society, and do not intend to stay longer in the receiving country. As a consequence, residents might assume that refugees are less motivated to adjust to the receiving society's customs and values, and are less willing to invest time in learning and skill development as compared to non-refugee migrants. These perceptions not only elicit negative, integration-impeding attitudes towards refugees, but might also trigger self-fulfilling prophecy cycles during which negative residents' expectations impede refugees' engagement and integration-relevant activities, which in turn increase negative reactions by residents.

Such integration-impeding responses should be attenuated by person factors such as residents' dispositional openness, empathic concern and positive attitudes towards migrants and their integration in the receiving society. In contrast, a perceived lack of migrants' (i.e., refugees') intrinsic interest in the receiving country might also be a strong cue to activate discriminating tendencies that are akin to residents with antagonistic traits such as a pro-self (vs. a prosocial) orientation, interpersonal coldness and arrogance (Wiggins, 1991), social dominance orientation and right-wing authoritarianism (Akrami, Ekehammar, \& Bergh, 2011). Interestingly, a limited future time perspective of migrants in the receiving country might sometimes reduce such negative reactions of residents. Consider the case of perceived competition for resources (e.g., about social welfare resources or job opportunities), which may emerge in residents who feel more (vs. less) similar to a given immigrant group (CostaLopes, Vala, \& Judd, 2012). These negative reactions toward immigrants might be lower 
when migrants are perceived to stay only for a limited time in the receiving country, and perceived rivalry about resources is not enduring and therefore less threatening for residents of a receiving country.

\section{Perceptions of Refugees' Privation}

When arriving in a receiving society, migrants in general face demands such as a new and unfamiliar environment, culture-specific practices and customs, loss of social and economic status (Fozdar \& Torezani, 2008; Kuo, 2014; Yakushko, 2010). Residents' empathic and helping responses can be intensified by the perception of privation and neediness (Khera, Harvey, \& Callan, 2014). Indeed, residents' recognition that refugee migrants have been subject to perils and suffering have been found to bolster perceptions of their neediness and related helping behavior (e.g., sharing of resources; Böhm, Theelen, Rusch, \& Van Lange, 2018; or benevolent actions, Becker, Ksenofontov, Siem, \& Love, 2018; Stürmer \& Siem, 2017). Relatedly, the belief that migrants were forced to leave their homes due to war or persecution enhances residents' support for granting asylum (Bansak et al., 2016; Kotzur et al., 2017) and endorsement of multiculturalism (Verkuyten, 2005). Social support from residents, and migrants' realization of residents' helping intentions, are both likely to facilitate individuals' coping with the demands and stressors of immigration (see Cobb et al., 2019).

The impact of perceived migration perils in residents' responses is even reflected by some migrants' strategies for enhancing their chances of being admitted and granted asylum status in a potential host country. For instance, migrants might pretend to come from different countries, sometimes with forged identity documents (Mekhennet \& Booth, 2015), when these countries are known for severe pre-migration perils in public discourses.

Interestingly, residents' perceptions of forcedness can also interact with perceptions of migration perils. For instance, in a recent study, the perception of refugees' migration plight and suffering elicited different emotional responses in host-society residents depending on 
perceived forcedness (Verkuyten, Mepham, \& Kros, 2018). Specifically, when residents perceived migration as forced (involuntary), they exhibited stronger empathy responses to migrants' migration perils and endorsed public assistance to migrants to a greater extent. This finding suggests that in this study perceived forcedness rather than perceived suffering per se moderates residents' responses to immigration-related demands (here, being confronted with unfamiliar and culturally different strangers).

The described effects on residents' empathic reactions to migration can be further moderated by person and context factors. Personality aspects such as residents' agreeableness and self-transcendence values, for example, are characterized by a general prosocial orientation, the valuation of communal goals, and the willingness to support those in need of help (e.g., Graziano, Habashi, Sheese, \& Tobin, 2007). Residents with higher values in such prosocial traits should have an increased tendency to feel empathy and provide help towards migrants whose migration they perceive as forced. Such prosocial tendencies can also be amplified in certain contexts. When the receiving society is, for example, characterized by a welcoming culture, empathy and help specifically towards refugees should be stronger. Also, with regard to post-arrival temporal delay, prosocial tendencies should be especially prevalent in the immediate post-arrival phase when perceived forcedness is more salient.

\section{Perceptions of Suffering and Violence}

Extant research shows that residents sometimes respond with feelings of anxiety to immigration into their society, which in turn trigger negative attitudes toward immigrants (Esses et al., 2017; Schmidt \& Weick, 2017; Ward \& Masgoret, 2006; Ward, Szabo, \& Stuart, 2016). Perceived forcedness and related perils should again qualify these resident reactions. Specifically, residents' perceptions of refugees' suffering and involvement in perilous conflicts can activate associations with violence and even terrorism (Wike, Stokes, \& Simmons, 2016). A recent study comparing comments to YouTube videos found that 
participants' responses contained more references to threat and violence when the title of the video contained the term "refugee crisis" versus "migrant crisis" (Lee \& Nerghes, 2018). Also, individuals who suffer from mental health problems due to their involvement in war and violence have been found to be stigmatized and perceived as unpredictable and dangerous by residents (Greene-Shortridge, Britt, \& Castro, 2007; Mittal et al., 2013). In a similar way, knowing that migrants have escaped from war regions might exacerbate residents' anxiety responses to immigration.

Extant research also indicates that perceptions of violence and related threats reduce endorsement of public policies for supporting refugees (Canetti, Snider, Pedersen, \& Hall, 2016; Hartley \& Pedersen, 2015). Moreover, such perceptions should induce residents to avoid contact with refugees, precluding or diminishing opportunities for stereotype and prejudice reduction (Pettigrew \& Tropp, 2006). Indeed, intergroup research suggests that residents' direct contact with migrants reduces prejudice by mitigating anxiety (Voci \& Hewstone, 2003) and threat responses to immigration (Pettigrew, Christ, Wagner, \& Stellmacher, 2007).

Anxiety responses to immigration are more likely for residents who already hold negative attitudes towards migrants and refugees. A recent study by Noor, Kteily, Siem, and Mazziotta (2018, Study 1) showed that residents with anti-immigration (vs. pro-immigration) attitudes were more likely to regard a refugee suicide-attacker in Germany as motivated by terrorism (vs. mental illness), which in turn predicted greater endorsement of punitive measures against refugees. Stronger negative responses of this sort might also be found for individuals with an increased sensitivity and reactivity to interpersonal threat (e.g., those high in neuroticism), and in contexts in which risks and threat of refugee integration are prominent in the media and in public discourse. Such responses are exemplified by reports from the city of St. Cloud (Minnesota, US): "Some opponents of the refugee program have taken the 
introduction of non-pork options in the local public schools as an attack on their way of life" (Herndon, 2019).

Furthermore, prejudice and discrimination responses to refugees should be intensified in residents with antagonistic traits such as social dominance orientation and right-wing authoritarianism (Akrami et al., 2011). Residents with such personality characteristics share negative attitudes towards minorities and subscribe to aggressive actions against those who do not fit their own majority-based ideas. Regarding context factors, residents' rejection tendencies should be stronger when the intergroup climate in a resident community is more hostile (Christ et al., 2013), when communities are culturally homogeneous contexts, and when cultural divergence of refugees is prominently stressed in the media and in public discourse. Again, the post-arrival temporal context might also play an important role in that rejection tendencies may increase over time: While positive, empathy-related responses should be more relevant to the immediate post-arrival phase, negative responses might be more likely to emerge later, that is, after the initial arrival phase.

\section{Testing the PARI Model for Residents}

As for refugees, empirical tests of our predictions should focus on examining how residents' perceptions of migrants' forcedness and perils of migration moderate effects of immigration demands and stressors on integration-relevant responses, including the psychological processes that mediate these effects of forcedness perceptions. To this end, researchers should assess and quantify the demands and stressors of the immigration situation, as well as residents' responses to these demands (e.g., empathy, attitudes, anxiety). Perceived forcedness (or perceived perils) should be included as moderator variable of the effects of immigration-related demands and stressors on integration-relevant processes and outcomes. We recommend that one or more of the proposed proximal psychological variables (e.g., 
perceived privation of migrants, perceived interest in the receiving society) be included as potential mediators of the effects of perceived forcedness and related perils.

As for refugees, person and context factors can be included as moderators of the proposed effects on integration-relevant responses. Such analyses need to implement a multilevel design, as described in the earlier section Testing the PARI Model for Refugees. The following methods can be employed to examine the proposed effects. First, the salience or cognitive accessibility of the immigration-based demands and stressors for the receiving society can be increased experimentally. Whereas manipulations of refugees' forcedness and peril experiences are not viable for obvious ethical (and practical) reasons, residents' perceptions of refugees' forcedness and peril can be experimentally varied, for instance, by enhancing the salience of the "push" factors and perilous circumstances of migration (see Bansak et al., 2016; Kotzur et al., 2017; Verkuyten et al., 2018). Alternatively, perceptions of forcedness and peril can be assessed with direct (self-report) and indirect measures (e.g., Gawronski \& De Houwer, 2014). Indirect measures could elicit residents' thoughts about the circumstances and reasons of migration of a specific refugee group, which can be coded for the degree of perceived forcedness and peril. The dependent measures should address responses relevant to integration, such as attitudes and feelings related to contact with refugee and non-refugee migrants, attitudes toward refugee integration, experienced threat and anxiety, but also empathy, helping behavior, the willingness to help. Additional evidence can be obtained through large-scale, representative surveys or the automatic extraction of media data, preferably with longitudinal designs.

Finally, another important avenue for future research is to observe patterns of social interactions between refugees and residents as they develop (spiral upwards or downwards) over time in settings such as work, education, and (mental) health. Such studies could profit 
from new techniques for experience sampling via mobile devices (Harari et al., 2016; Wrzus \& Mehl, 2015).

\section{Implications for Applied Fields}

The PARI model is relevant for various domains of integration-relevant outcomes. In the current paper, we illustrate the implications for three key domains of integration, namely occupational work, education, and mental health. In the work domain, a better understanding of the psychological effects of forcedness on migrants' coping with challenges of the receiving country's job market can provide helpful strategies to support enduring integration of refugees (Wehrle et al., 2019). According to the PARI model, refugees as compared to voluntary migrants might need more support and flexibility particularly during the first time after arrival in the receiving country in order to cope with traumatic experiences and to adjust to an environment which they have not chosen voluntarily. A long-term future time perspective would be particularly helpful in this early stage to increase refugees' motivation to invest their (initially restricted) resources in job trainings and further education. Such investments might be beneficial for the receiving society not only in light of demographic changes and skills shortages (e.g., Hertel \& Zacher, 2018). Over time, forced migrants might even develop higher commitments and engagement in the receiving country when the situation in the home country remains hostile (e.g., Cortes, 2004). In contrast, legal regulations which restrict refugees' future time perspectives in the receiving country even after initial occupational integration are detrimental for the motivation and (mental) health of refugees, and also prevent benefits from additional resources for the new job market. In addition to interventions focusing on refugee migrants, the PARI model also provides a better understanding of residents' responses at the workplace. Indeed, employers, supervisors, and colleagues are among the most important agents of refugee integration. Supporting an open and supportive attitude toward refugee migrants at work is critical for successful integration. To promote such a positive climate, 
information and training of supervisors and colleagues is certainly desirable, as well as a longer time perspective so that personal investments pay off. However, residents should also be assured that integrating migrants is not in conflict with their own job-related resources and perspectives.

Concerning the field of early childhood education and development, immigration challenges beliefs concerning ideal education and childcare in host countries. The absorption of resources needed to regain a mastery and control may exacerbate migrants' sense of symbolic threat from cultural differences. Education is a domain for which such effects are of vital importance. Migrants are often confronted with alternative or incompatible ideals on optimal parenting, education, and child development that threaten deeply held beliefs concerning education and childcare (e.g., Greenfield, Keller, Fuligni, \& Maynard, 2003; Renzaho, McCabe, \& Sainsbury, 2011; Rogoff, Paradise, Mejía Arauz, Correa-Chávez, \& Angelillo, 2003). A preoccupation with regaining mastery and control should restrict migrants' openness to alternative conceptions of early childhood education. Thus, while refugees are struggling with restoring basic needs, they are less likely than non-refugee migrants to find ways of accommodating culturally different notions of education and childhood care. Due to the circumstances of forced migration, refugees' residential status is transitory and uncertain, which should restrict their motivation to consider or accept alternative views of teaching and childhood care. Analogously, when refugees' uncertain future perspective is particularly salient, teachers may be less likely to pursue long-term educational goals in their teaching of refugee children. Future studies should focus on developing training programs that capitalize on the specificities of forced versus voluntary migration to advance successful integration.

Concerning mental health, the PARI model is in line with empirical findings showing that refugees report higher levels of mental-health complaints than do other groups of migrants 
(Priebe et al., 2016), which are likely to result from forcedness and associated perils as well as post-arrival stressors. Thus, large groups of refugees may initially need specific mental health programs to better cope with the aftermath of migration forcedness and post-arrival demands. In addition to lack of knowledge about health services in the receiving country or poor command of the new language, the experience of migration perils might hamper refugees' willingness to access these services. Interpersonal traumatic events before or during migration might induce beliefs that increase lack of trust in health professionals and thus prevent refugees from seeking medical or psychological help (Jankovic et al., 2011; Marshall, Butler, Roche, Cumming, \& Taknint, 2016; Priebe et al., 2016). Moreover, the characteristics of forced (vs. more voluntary) migration may restrict or vie for the resources needed for bereavement, especially shortly after arrival in the receiving society. According to our rationale, a severe sense of control loss and a limited or uncertain future time perspective may impede functional coping with mental-health complaints.

Consistent with the PARI model, the interplay between the demands and stressors from immigration, integration-relevant psychological responses, and perceptions of forcedness and related perils should also influence mental health. Future studies on this interplay will inform mental health sciences in designing more effective preventive as well as therapeutic programs aimed at increasing resilience among newly arrived refugees or reducing mental health complaints for those in need of current care. This, in turn, is likely to facilitate integrationrelevant psychological processes and integration-relevant outcomes. The socio-structural conceptualization of integration further suggests that successful social, educational and occupational integration of refugees in the receiving society will increase refugees' wellbeing, mental health and life satisfaction in general (Seligman, in press). 


\section{Conclusion and Perspectives}

With the PARI model, we have proposed a model for analyzing and understanding psychological antecedents of refugee integration, which has developed into a pressing issue of global dimensions. Our approach fills a lacuna in existing models, which have not yet been custom-tailored to the specificities of refugee migration. Importantly, we conceptualize perceived forcedness as the core dimension on which refugee migration differs from other forms of migration. We suggest that refugees' and residents' perceptions of forcedness and related perils moderate integration-relevant psychological responses to the challenges of immigration in specific ways. Importantly, we have identified psychological factors (e.g., refugees' loss of control, external attribution, residents' perceptions of refugees' privation and suffering) that should mediate the effects of forcedness on the link between challenges from immigration and individual responses. This analysis allowed us to delineate predictions concerning refugee-specific and integration-relevant psychological responses, and the person and context characteristics that moderate these effects. Moreover, we also considered how individuals' resources might be affected by forced as compared to voluntary migration.

The contribution of our model is primarily conceptual. We encourage researchers interested in refugee integration to consider the PARI model and derived predictions when planning empirical studies. As empirical evidence accrues, we will be in a better position to provide concrete recommendations for policy makers and practitioners. Consider, for instance, the suggested effects of refugees' control loss from forcedness. Should our reasoning on these effects receive empirical support, the integration-impeding effects of forcedness could be countered by trainings of self-efficacy (for an example in the work domain, see Schwoerer, May, Hollensbe, \& Mencl, 2005), which need to be adapted to the needs of refugees. Such insights could also be employed to better prepare refugees for their stay in a receiving country prior to arrival. 
We note that the post-arrival effects of migration-related perils may vary depending on the specific type of peril and refugees' individual perceptions and attributions of perils. Some perils, such as adverse environmental conditions from climate change or intractable civil war, are likely to persist for many years or even decades. Pre-migration perils that have been experienced over a long (vs. short) period of time and are perceived as stable (vs. variable) should restrain or diminish the wish to return home in the face of difficult post-arrival conditions. Further differentiation between the effects of various pre-migration perils is warranted but beyond the scope of this paper.

For residents, we have described potential integration-impeding effects of perceiving forced (vs. regular) migrants as less interested in the receiving society. A corresponding intervention could be to provide residents with illustrative information or narratives about individual refugees who are engaged in cultural learning about the host culture or perhaps to provide both parties with the opportunity to learn directly about the other one's culture.

While we have covered a broad range of different literatures and relevant approaches, there are issues still to be developed in future analyses. First, our focus on post-arrival perceptions of forcedness begs the question of how such perceptions emerge and take shape. This issue concerns factors and predictors of forcedness perceptions. For refugees, a key predictor are the actual pre-migration perils and push factors experienced in the home country. However, after arrival in the receiving society, there are potential other predictors. Possible cognitive predictors include the (context-dependent) accessibility of related knowledge and memories, and the salience of potentially relevant stimuli (Higgins, 1996). Memories of being forced to leave home should be particularly clear and strong shortly after arrival in a receiving society, sustaining perceptions of forcedness. Such memories can be perpetuated by reminders such as other refugees' migration testimonies, questions or queries by members of the receiving society, or images and reports in the media. 
Possible motivational predictors are needs or incentives (i.e., intrinsic or extrinsic motives) to construe and remember one's own emigration as more or less forced. For instance, migrants strongly identifying with a group that is severely victimized in their home country (e.g., Yazidis from Iraq) may partly derive perceptions of forcedness from collective memories or group-based norms, in addition to perceptions based on their own individual experience. Also, being categorized as a "refugee" is likely to evoke images of passive, needy, and incompetent victims, which can be experienced as stigmatizing by refugees (Fiske, 2018; FitzGerald \& Arar, 2018; Ludwig, 2016; Rajaram, 2002; for an example, see La6izi Community, 2019). As a recent newspaper report about a Syrian refugee put it: "Being called a refugee, that's bad branding" (our translation from German, "Ein Flüchtling zu sein, das ist eine schlechte Marke"; Bogner \& Hertzberg, 2019). Thus, refugees may want to construe their emigration as more actively chosen and, thus, less forced. Such a perception of low forcedness would by supported, for instance, by construing the departure from the home country as a situation of taking action and re-gaining personal control.

Residents' perceptions of migrants' forcedness can stem from various sources, such as (social) media reports, public discourse including rumors and political debates, direct or indirect contact with refugees, or lay theories about refugee migration. As for refugees, residents' perceptions of migrants' forcedness could also be shaped by the context-dependent accessibility and salience of related knowledge about refugees' presumable reasons for fleeing their home country. For instance, merely activating the label of "refugee" may generally induce residents to view a migrant as being more (vs. less) forced by push factors in the home country (see Kotzur et al., 2017; Zetter, 1991).

Motivational factors concern residents' propensity to regard immigrants as needy victims or as sources of threat, and their need to justify their attitudes and affective responses to immigration. For instance, evidence suggests that residents selectively process information 
on refugees provided by the media to justify their preexisting negative responses to refugees, especially when they experience frustration of basic needs by the arrival of refugees (Lüders, Prentice, \& Jonas, 2019). In this case, motivated information processing would induce residents to perceive refugees' migration as driven by their own self-interests rather than external forces. These processes deserve further analysis and investigation.

In the course of describing proposed effects of forcedness and perils on refugees' integration-relevant responses to immigration we have considered the possible role of person factors, which include individual resources for coping with immigration-related stressors (Kuo, 2014; Ryan, Dooley, \& Benson, 2008). In addition to the main predictions of our model, it is possible that different personal resources are more or less affected by distinctive refugee experiences, that is, forcedness and related perils. We suspect that, on the one hand, socioemotional resources can potentially be altered by these refugee experiences. In our model, such effects could be represented by an additional path from perceptions of forcedness and related perils to person factors in Figure 1. For instance, strong forcedness of emigration and severe related perils or traumatic experiences can have detrimental effects on a refugees' openness, emotional stability, agreeableness, generalized trust, which would impede adaptation and integration in the receiving society. On the other hand, more "crystallized" individual resources, such as level of education, cultural intelligence, wisdom, or collectivistic orientation, remain available across the migration process. To manage their transition successfully, refugees should actively employ these resources.

In a similar vein, forcedness and related perils may affect integration-relevant context factors. For instance, because forced (vs. voluntary) migrants have little control over the course and circumstances of their transition, they are likely to lose contact with existing premigration social networks (family, friends, in-groups) during their transition. A specific challenge for refugees, then, is to keep or re-establish contact with pre-migration networks and 
to build new support networks in the receiving society. Distressing and threatening postmigration conditions should induce them to seek greater affiliation and connectedness with social networks or in-groups (see Baumeister \& Leary, 1995; Taylor, 2002).

The development of new social networks through affiliation with in-groups may be affected by the categorization as a "refugee." Many refugees perceive differences between refugee groups, such as Syrians, Afghans, or Eritreans (see Marsella, 1994). Thus, refugees are likely to feel that the externally assigned, broader label "refugee" fails to capture central aspects of their identity in relation to their long-standing identification with a (e.g., national or ethnic) group (Zetter, 2007). According to self-categorization theory (Turner, Hogg, Oakes, Reicher, \& Wetherell, 1987), feelings of belonging do not result from mere group membership but rather from the centrality and internalization of one's group identity. To the extent that the categorization as a refugee is less central and less internalized, refugees are less likely to reap psychological benefits, particularly feelings of belonging and meaning, from membership in this group (for a related argument for migrants in general, see Cobb et al., 2019). It would be interesting to explore these additional hypotheses in empirical studies.

Another open issue concerns the role of refugees' meta-perceptions of the refugee stereotype. Such meta-perceptions can have consequences for refugees' coping, wellbeing, and ultimately, integration. To the extent that refugees are aware of residents' stereotypes, they are likely to feel barriers to being respected and trusted. According to research on intergroup interactions (e.g., Major, Quinton, \& McCoy, 2002), refugees may thus enter interactions with host-society residents with the anticipation of being treated as passive, incompetent, untrustworthy and needy victims. This anticipation, in turn, may induce negative affective reactions, such as anxiety, and a preoccupation with monitoring the others' reactions and potential stereotype confirmation (see Shelton \& Richeson, 2006). Such anxiety and 
uncertainty may ultimately result in self-fulfilling prophecies, which would undermine wellbeing, adaptation, and, ultimately, integration efforts.

Refugees holding such meta-stereotypes and anticipations may attempt to counteract and overcome residents' prejudice in interactions, for instance, be trying to appear as an exception from the stereotype, and by attempting to make a personal connection (Shelton \& Richeson, 2006). However, given the real (legal and material) benefits of being assigned the refugee status (Ludwig, 2016), arriving refugees who are not yet granted this status may try to portray themselves in stereotype-consistent ways. Thus, time after arrival in the receiving country should moderate the emergence of these effects.

Depending on their attitudes towards refugees and refugee integration and their metaperceptions, residents of the receiving society may avoid contact and interactions, experience uncertainty and anxiety when entering interactions with refugees, or may try to portray themselves as benevolent and empathic. As noted above, these effects should be moderated by residents' assumptions or perceptions of refugees' forcedness of migration and resulting suffering. For instance, concerns about appearing empathic and benevolent should increase with increasing perceptions of forcedness and suffering.

In a similar vein, continued social interaction between refugees and residents could shape integration-relevant responses by both refugees and residents. Comparisons with culturally distant others and initial reactions by host-society residents, ranging from empathic and welcoming to avoidant and hostile, may alter refugees' meta-perceptions about themselves, which in turn can shape refugees' integration-relevant responses and adaptation to the new environment. Conversely, refugees' integration efforts and adjustment processes can also alter residents' views of refugees and their reactions toward refugees. Such mutual influences are likely to be shaped by direct interactions between members of the two groups. 
To capture such processes, researchers should investigate intergroup interaction, types of contact, and related cognitive and emotional responses (Shelton \& Richeson, 2006).

To investigate such integration-relevant social interaction processes, research needs to

(a) specify the exact process chains within and across social interaction units by which initial experiences towards refugees/residents translate into observable interaction behaviors, emerging relational perceptions, and social outcomes, and (b) simultaneously consider individual (i.e., perceiver/actor and target/partner) as well as relational (i.e., dyadic) influences on these processes (see Back et al., 2011). Such analyses require the advanced methods of data acquisitions that are able to capture experiences and behaviors of multiple interaction partners in the moment (Hopwood et al., 2016; Wrzus \& Mehl, 2015). This might include eventcontingent recordings using experience-sampling designs (e.g., Fournier, Moskowitz, \& Zuroff, 2008; van Zalk, Nestler, Geukes, Hutteman, \& Back, 2019) as well as the continuous recording of interpersonal reaction within social interactions (Markey, Lowmaster, \& Eichler, 2010; Ross et al., 2017).

Finally, we also recognize that migrants' adjustment to new living conditions requires cultural learning, that is, the acquisition of practices, skills, norms, and language competencies that are helpful or needed to participate in the receiving society (Masgoret \& Ward, 2006). We have noted such processes intermittently in the presentation of our model. However, an indepth discussion of cultural learning requires an approach that would go beyond the scope of the present paper.

All in all, the PARI model offers added value in several respects. It will allow researchers to (a) capture the relevant psychological phenomena more precisely, (b) improve explanations and predictions of adjustment and integration, (c) develop or improve interventions for promoting successful integration and wellbeing, and (d) ultimately provide 
policy-makers and practitioners with scientific insights that speak directly to the eminent societal and political challenges of refugee integration. 


\section{References}

Abele, A. E., \& Wojciszke, B. (2007). Agency and communion from the perspective of self versus others. Journal of Personality and Social Psychology, 93(5), 751-763. https://doi.org/10.1037/0022-3514.93.5.751

Ager, A. (1999). Perspectives on the refugee experience. In A. Ager (Ed.), Refugees: Perspectives on the experience of forced migration (pp. 1-23). New York, NY: Continuum.

Ager, A., \& Strang, A. (2008). Understanding integration: A conceptual framework. Journal of Refugee Studies, 21(2), 166-191. https://doi.org/10.1093/jrs/fen016

Ahmed, A. S. (2007). Post-traumatic stress disorder, resilience and vulnerability. Advances in Psychiatric Treatment, 13(5), 369-375. https://doi.org/10.1192/apt.bp.106.003236

Akrami, N., Ekehammar, B., \& Bergh, R. (2011). Generalized prejudice: Common and specific components. Psychological Science, 22(1), 57-59. https://doi.org/10.1177/0956797610390384

Aldwin, C. M. (1994). Stress, coping, and development. New York, NY: Guilford.

Allen, J., Vaage, A. B., \& Hauff, E. (2006). Refugees and asylum seekers in societies. In D. L. Sam \& J. W. Berry (Eds.), The Cambridge handbook of acculturation psychology (pp. 198-217). Cambridge, UK: Cambridge University Press.

Amjahid, M. (2015). Die Kraft der Bilder: Die Kehrseite der Willkommenskultur. [The power of images: The dark side of the welcome culture]. In A. Reschke (Ed.), Und das ist erst der Anfang: Deutschland und die Flüchtlinge [And that is only the beginning: Germany and the refugees]. Reinbek, Germany: Rowohlt.

Arnetz, J., Rofa, Y., Arnetz, B., Ventimiglia, M., \& Jamil, H. (2013). Resilience as a protective factor against the development of psychopathology among refugees. The 
Journal of Nervous and Mental Disease, 201(3), 167-172.

https://doi.org/10.1097/NMD.0b013e3182848afe

Aron, A. (1992). Applications of psychology to the assessment of refugees seeking political asylum. Applied Psychology: An International Review, 41(1), 77-91. https://doi.org/10.1111/j.1464-0597.1992.tb00687.x

Arts Council England (2019, May 24). Blanket project takes women's stories across the world. Retrieved from https://www.artscouncil.org.uk/news/blanket-project-takeswomen\%E2\%80\%99s-stories-across-world

Back, M. D., Baumert, A., Denissen, J. J. A., Hartung, F.-M., Penke, L., Schmukle, S. C., ... \& Wrzus, C. (2011). PERSOC: A unified framework for understanding the dynamic interplay of personality and social relationships. European Journal of Personality, 25(2), 90-107. https://doi.org/10.1002/per.811

Bandura, A. (1997). Self-efficacy: The exercise of control. New York, NY: Freeman.

Bansak, K., Hainmueller, J., \& Hangartner, D. (2016). How economic, humanitarian, and religious concerns shape European attitudes toward asylum seekers. Science, 354(6309), 217-222. https://doi.org/10.1126/science.aag2147

Barnard, A., \& Saad, H. (2018, February 8). It's hard to believe, but Syria's war is getting even worse. The New York Times. Retrieved from https://nytimes.com

Baumeister, R. F., \& Leary, M. R. (1995). The need to belong: Desire for interpersonal attachments as a fundamental human motivation. Psychological Bulletin, 117, 497-529.

Bayes, M. A. (1972). Behavioral cues of interpersonal warmth. Journal of Consulting and Clinical Psychology, 39(2), 333-339. https://doi.org/10.1037/h0033367

Becker, J. C., Ksenofontov, I., Siem, B., \& Love, A. (2018). Antecedents and consequences of autonomy- and dependency-oriented help toward refugees. European Journal of Social Psychology. Advance online publication. https://doi.org/10.1002/ejsp.2554 
Beiser, M., Turner, R. J., \& Ganesan, S. (1989). Catastrophic stress and factors affecting its consequences among Southeast Asian refugees. Social Science and Medicine, 28(3), 183-195.

Berry, J. W. (1980). Social and cultural change. In H. C. Triandis \& R. Brislin (Eds.), Handbook of cross-cultural psychology (pp. 211-279). Boston, MA: Allyn \& Bacon.

Berry, J. W. (1997). Immigration, acculturation, and adaptation. Applied Psychology: An International Review, 46(1), 5-68. https://doi.org/10.1111/j.1464-0597.1997.tb01087.x

Berry, J. W. (2003). Conceptual approaches to acculturation. In K. M. Chun, P. Balls Organista, \& G. Marín (Eds.), Acculturation: Advances in theory, measurement, and applied research (pp. 17-37). Washington, DC, US: American Psychological Association.

Berry, J. W. (2005). Acculturation: Living successfully in two cultures. International Journal of Intercultural Relations, 29(6), 679-712. https://doi.org/10.1016/j.ijintrel.2005.07.013

Berry, J. W. (2009). A critique of critical acculturation. International Journal of Intercultural Relations, 33(5), 361-371. https://doi.org/10.1016/j.ijintrel.2009.06.003

Berry, J. W., Kim, U., Minde, T., \& Mok, D. (1987). Comparative studies of acculturative stress. International Migration Review, 21(3), 491-511. https://doi.org/10.1177/019791838702100303

Betts, A. (2010). Survival migration: A new protection framework. Global Governance, 16(3), $361-382$.

Betts, A., \& Collier, P. (2017). Refuge: Transforming a broken refugee system. Oxford, UK: Oxford University Press.

Böhm, R., Theelen, M. M. P., Rusch, H., \& Van Lange, P. A. M. (2018). Costs, needs, and integration efforts shape helping behavior toward refugees. Proceedings of the 
National Academy of Science, 115(28), 7284-7289.

https://doi.org/10.1073/pnas.1805601115

Bogner, S., \& Hertzberg, P. (2019, June 23). Ein Syrer in Ghana: Flucht nach Afrika [A Syrian in Ghana: Flight to Africa]. Frankfurter Allgemeine Zeitung. Retrieved from https://www.faz.net/aktuell/gesellschaft/menschen/das-neue-leben-eines-syrers-dernach-ghana-floh-16247538.html

Bonanno, G. A. (2004) Loss, trauma, and human resilience: have we underestimated the human capacity to thrive after extremely aversive events? American Journal of Psychology, 59(1), 20-28. https://doi.org/10.1037/0003-066X.59.1.20

Bourhis, R. Y., Moïse, L. C., Perreault, S., \& Senécal, S. (1997). Towards an interactive acculturation model: A social psychological approach. International Journal of Psychology, 32(6), 369-386. https://doi.org/10.1080/002075997400629

Brannan, S., Campbell, R., Davies, M., English, V., Mussell, R., \& Sheather, J. C. (2016). The Mediterranean refugee crisis: Ethics, international law and migrant health. Journal of Medical Ethics, 42(4), 269-270. https://doi.org/10.1136/medethics-2016-103444

Bronstein, I., \& Montgomery, P. (2011). Psychological distress in refugee children: A systematic review. Clinical Child and Family Psychology Review, 14(1), 44-56. https://doi.org/10.1007/s10567-010-0081-0

Brown, T. A., \& Rosellini, A. J. (2011). The direct and interactive effects of neuroticism and life stress on the severity and longitudinal course of depressive symptoms. Journal of Abnormal Psychology, 120(4), 844-856. https://doi.org/10.1037/a0023035

Canetti, D., Snider, K. L. G., Pedersen, A., \& Hall, B. J. (2016). Threatened or threatening? How ideology shapes asylum seekers' immigration policy attitudes in Israel and Australia. Journal of Refugee Studies, 29(4), 583-606.

https://doi.org/10.1093/jrs/few012 
Carlsson, J., \& Sonne, C. (2018). Mental health, pre-migratory trauma and post-migratory stressors among adult refugees. In N. Morina \& A. Nickerson (Eds.), Mental health of refugee and conflict-affected populations: Theory, research and clinical practice (pp. 15-36). Cham, Switzerland: Springer Nature.

Carstensen, L. L. (2006). The influence of a sense of time on human development. Science, 312(5782), 1913-1915. https://doi.org/10.1126/science.1127488

Castles, S. (2003). Towards a sociology of forced migration and social transformation. Sociology, 37(1), 13-34. https://doi.org/10.1177/0038038503037001384

Castro, F. G., \& Murray, K. E. (2010). Cultural adaptation and resilience: Controversies, issues, and emerging models. In J. W. Reich, A. J. Zautra, \& J. S. Hall (Eds.), Handbook of adult resilience (pp. 375-403). New York, NY: Guilford Press.

Chimni, B. S. (2004). From resettlement to involuntary repatriation: Towards a critical history of durable solutions to refugee problems. Refugee Survey Quarterly, 23, 55-73. https://doi.org/10.1093/rsq/23.3.55

Chimni, B. S. (2009). The birth of a 'discipline': From refugee to forced migration studies. Journal of Refugee Studies, 22(1), 11-29. https://doi.org/10.1093/jrs/fen051

Christ, O., Asbrock, F., Dhont, K., Pettigrew, T. F., \& Wagner, U. (2013). The effects of intergroup climate on immigrants' acculturation preferences. Zeitschrift für Psychologie, 221(4), 252-257. https://doi.org/10.1027/2151-2604/a000155

Christ, O., Schmid, K., Lolliot, S., Swart, H. Stolle, D., Tausch, N., .. \& Hewstone, M. (2014). Contextual effect of positive intergroup contact on outgroup prejudice. Proceedings of the National Academy of Sciences, 111(11), 3996-4000. https://doi.org/10.1073/pnas.1320901111

Christmas, C. N., \& Barker, G. G. (2014). Assessing intercultural experience: Differences in acculturation, intercultural sensitivity, and cognitive flexibility between the first and 
second generation of Latino immigrants. Journal of International and Intercultural Communication, 7(3), 238-257. https://doi.org/10.1080/17513057.2014.929202

Cobb, C. L., Branscombe, N. R., Meca, A., Schwartz, S. J., Xie, D., Zea, M. C., ... \& Martinez, C. R. (2019). Toward a positive psychology of immigrants. Perspectives on Psychological Science, 14(4), 619-632. https://doi.org/10.1177/1745691619825848

Cortes, K. E. (2004). Are refugees different from economic migrants? Some empirical evidence on the heterogeneity of immigrant groups in the United States. The Review of Economics and Statistics, 86(2), 465-480.

https://doi.org/10.1162/003465304323031058

Costa-Lopes, R., Vala, J., \& Judd, C. M. (2012). Similarity and dissimilarity in intergroup relations: Different dimensions, different processes. Revue Internationale de Psychologie Sociale, 25(1), 31-65.

Deaux, K., \& Verkuyten, M. (2014). The social psychology of multiculturalism: Identity and intergroup relations. In V. Benet-Martínez \& Y.-y. Hong (Eds.), The Oxford handbook of multicultural identity (pp. 118-138). New York: Oxford University Press.

Deci, E. L., \& Ryan, R. M. (2000). The "what" and "why" of goal pursuits: Human needs and the self-determination of behavior. Psychological Inquiry, 11(4), 227-268. https://doi.org/10.1207/S15327965PLI1104_01

De Vries, J., \& Van Heck, G. L. (1994). Quality of life and refugees. International Journal of Mental Health, 23(3), 57-75. https://doi.org/10.1080/00207411.1994.11449287

Doná, G., \& Berry, J. W. (1999). Refugee acculturation and re-acculturation. In A. Ager (Ed.), Refugees: Perspectives on the experience of forced migration (pp. 169-195). New York, NY: Continuum. 
El-Shaarawi, N. (2015). Living an uncertain future: Temporality, uncertainty, and well-being among Iraqi refugees in Egypt. Social Analysis, 59(1), 38-56. https://doi.org/10.3167/sa.2015.590103

Erdal, M. B., \& Oeppen, C. (2018). Forced to leave? The discursive and analytical significance of describing migration as forced and voluntary. Journal of Ethnic and Migration Studies, 44(6), 981-998. https://doi.org/10.1080/1369183X.2017.1384149

Esses, V. M., Hamilton, L. K., \& Gaucher, D. (2017). The global refugee crisis: Empirical evidence and policy implications for improving public attitudes and facilitating refugee resettlement. Social Issues and Policy Review, 11(1), 78-123. https://doi.org/10.1111/sipr.12028

Essuman-Johnson, A. (2011). When refugees don't go home: The situation of Liberian refugees in Ghana. Journal of Immigrant \& Refugee Studies, 9(2), 105-126. https://doi.org/10.1080/15562948.2011.567139

Fazel, M., Reed, R. V., Panter-Brick, C., \& Stein, A. (2012). Mental health of displaced and refugee children resettled in high-income countries: Risk and protective factors. The Lancet, 379(9812), 266-282. https://doi.org/10.1016/S0140-6736(11)60051-2

Fiske, S. T. (2018). Stereotype content: Warmth and competence endure. Current Directions in Psychological Science, 27, 67-73. https://doi.org/10.1177/0963721417738825

Fiske, S. T., Rosenblum, K. E., \& Travis, T. M. C. (2004). Social beings: A core motives approach to social psychology. New York, NY: Wiley.

FitzGerald, D. G., \& Arar, R. (2018). The sociology of refugee migration. Annual Review of Sociology, 44, 387-406. https://doi.org/10.1146/annurev-soc-073117-041204

Flaskerud, J. H., \& Uman, G. (1996). Acculturation and its effects on self-esteem among immigrant Latina women. Behavioral Medicine, 22(3), 123-133. https://doi.org/10.1080/08964289.1996.9933773 
Fournier, M. A., Moskowitz, D. S., \& Zuroff, D. C. (2008). Integrating dispositions, signatures, and the interpersonal domain. Journal of Personality and Social Psychology, 94(3), 531-545. https://doi.org/10.1037/0022-3514.94.3.531

Fozdar, F., \& Torezani, S. (2008). Discrimination and well-being: Perceptions of refugees in Western Australia. International Migration Review, 42(1), 30-63. https://doi.org/10.1111/j.1747-7379.2007.00113.x

Frater-Mathieson, K. (2004). Refugee trauma, loss and grief: Implications for intervention. In R. Hamilton \& D. Moore (Eds.), Educational interventions for refugee children (pp. 12-34). London, U.K.: Routledge.

Freitag, M., \& Bauer, P. (2016). Personality traits and the propensity to trust friends and strangers. The Social Science Journal, 53(4), 467-476. https://doi.org/10.1016/j.soscij.2015.12.002

Gawronski, B., \& De Houwer, J. (2014). Implicit measures in social and personality psychology. In H. T. Reis \& C. M. Judd (Eds.), Handbook of research methods in social and personality psychology (2nd ed., pp. 283-310). New York, NY: Cambridge University Press.

Geeraert, N., Li, R., Ward, C., Gelfand, M., \& Demes, K. A. (2019). A tight spot: How personality moderates the impact of social norms on sojourner adaptation. Psychological Science, 30(3), 333-342. https://doi.org/10.1177/0956797618815488

Glickman, K., Shear, M. K., \& Wall, M. M. (2017). Mediators of outcome in complicated grief treatment. Journal of Clinical Psychology, 73, 817-828.

Gorst-Unsworth, C., \& Goldenberg, E. (1998). Psychological sequelae of torture and organised violence suffered by refugees from Iraq: Trauma-related factors compared with social factors in exile. The British Journal of Psychiatry, 172(1), 90-94. https://doi.org/10.1192/bjp.172.1.90 
Gostin, L. O., \& Roberts A. E. (2015). Forced migration: The human face of a health crisis. JAMA, 314(20), 2125-2126. https://doi.org/10.1001/jama.2015.14906

Graziano, W. G., Habashi, M. M., Sheese, B. E., \& Tobin, R. M. (2007). Agreeableness, empathy, and helping: A person X situation perspective. Journal of Personality and Social Psychology, 93(4), 583-599. https://doi.org/10.1037/0022-3514.93.4.583

Greene-Shortridge, T. M., Britt, T. W., \& Castro, C. A. (2007). The stigma of mental health problems in the military. Military Medicine, 172(2), 157-161.

Greenfield, P. M., Keller, H., Fuligni, A., \& Maynard, A. (2003). Cultural pathways through universal development. Annual Review of Psychology, 54, 461-490. https://doi.org/10.1146/annurev.psych.54.101601.145221

Gross, J. J. (1998). The emerging field of emotion regulation: An integrative review. Review of General Psychology, 2(3), 271-299. https://doi.org/10.1037/1089-2680.2.3.271

Gudykunst, W. B. (1995). Anxiety/uncertainty management (AUM) theory: Current status. In R. L. Wiseman (Ed.), Intercultural communication theory (pp. 8-57). Thousand Oaks, CA: Sage.

Harari, G. M., Lane, N., Wang, R., Crosier, B., Campbell, A. T., \& Gosling, S. D. (2016). Using smartphones to collect behavioral data in psychological science: Opportunities, practical considerations, and challenges. Perspectives on Psychological Science, 11(6), 838-854. https://doi.org/10.1177/1745691616650285

Harrell-Bond, B. (1999). The experience of refugees as recipients of aid. In A. Ager (Ed.), Refugees: Perspectives on the experience of forced migration (pp. 136-168). New York, NY: Continuum.

Hartley, L. K., \& Pedersen, A. (2015). Asylum seekers and resettled refugees in Australia: Predicting social policy attitude from prejudice versus emotion. Journal of Social and Political Psychology, 3(1), 179-197. https://doi.org/10.5964/jspp.v3i1.476 
Haugen, I., \& Kunst, J. R. (2017). A two-way process? A qualitative and quantitative investigation of majority members' acculturation. International Journal of Intercultural Relations, 60, 67-82. https://doi.org/10.1016/j.ijintrel.2017.07.004

Herndon, A. W. (2019, June 20). 'These people aren't coming from Norway': Refugees in a Minnesota city face a backlash. The New York Times. Retrieved from https://www.nytimes.com/2019/06/20/us/politics/minnesota-refugees-trump.html

Hertel, G., Hellmann, J. H., \& Echterhoff, G. (2017). Occupational future time perspective as moderator of refugees' labor market integration. Paper presented at the $10^{\text {th }}$ Conference of the Work-, Organizational- and Business Psychology Division of the German Psychological Society, Dresden, Germany.

Hertel, G., \& Zacher, H. (2018). Managing the aging workforce. In D. S. Ones, N. Anderson, C. Viswesvaran, \& H. K. Sinangil (Eds.), The Sage handbook of industrial, work, \& organizational psychology (2nd ed., Vol. 3, pp. 396-428). Thousand Oakes, CA: Sage.

Hicks, J. A., Trent, J., Davis, W. E., \& King, L. A. (2012). Positive affect, meaning in life, and future time perspective: An application of socioemotional selectivity theory. Psychology and Aging, 27(1), 181-189. https://doi.org/10.1037/a0023965

Higgins, E. T. (1996) Knowledge activation: Accessibility, applicability, and salience. In E. T. Higgins \& A. W. Kruglanski (Eds.), Social psychology: Handbook of basic principles (pp. 133-168). New York, NY: Guilford.

Higgins, E. T. (2012). Beyond pleasure and pain: How motivation works. New York, NY: Oxford University Press.

Hogan, R., \& Blickle, G. (2018). Socioanalytic theory: Basic concepts, supporting evidences, and practical implications. In V. Zeigler-Hill \& T. K. Shackelford (Eds.), The Sage handbook of personality and individual differences (pp. 110-129). Thousand Oaks, CA: Sage. 
Holland, S. J., Shore, D. B., \& Cortina, J. M. (2017). Review and recommendations for integrating mediation and moderation. Organizational Research Methods, 20(4), 686720. https://doi.org/10.1177/1094428116658958

Hopwood, C. J., Thomas, K. M., Luo, X., Bernard, N., Lin, Y., \& Levendosky, A. A. (2016). Implementing dynamic assessments in psychotherapy. Assessment, 23, 507-517.

Human Rights Watch (2019, July 26). Turkey forcibly returning Syrians to danger: Authorities detain, coerce Syrians to sign "voluntary return” forms. Retrieved from https://www.hrw.org/news/2019/07/26/turkey-forcibly-returning-syrians-danger

International Organization for Migration (2009). Migration, environment and climate change: Assessing the evidence. Retrieved from publications.iom.int/system/files/pdf/migration_and_environment.pdf Iqbal, N. (2019, July 28). A stitch in time: How craftivists found their radical voice. The Guardian. Retrieved from https://www.theguardian.com/world/2019/jul/28/craftivismprotest-women-march-donald-trump

James, P. (2014). Faces of globalization and the borders of states: From asylum seekers to citizens. Citizenship Studies, 18(2), 208-223.

https://doi.org/10.1080/13621025.2014.886440

Jankovic, J., Vidakovic, I., Matanov, A., Schützwohl, M., Ljubotina, D., Lecic-Tosevski, D., \& Priebe, S. (2011). Reasons for not receiving treatment in people with posttraumatic stress disorder following war. The Journal of Nervous and Mental Disease, 199(2), 100-105. https://doi.org/10.1097/NMD.0b013e3182083db5

Joseph, S., \& Linley, P. A. (2005). Positive adjustment to threatening events: An organismic valuing theory of growth through adversity. Review of General Psychology, 9, 262280. 
Keles, S., Idsøe, T., Friborg, O., Sirin, S., \& Oppedal, B. (2017). The longitudinal relation between daily hassles and depressive symptoms among unaccompanied refugees in Norway. Journal of Abnormal Child Psychology, 45(7), 1413-1427. https://doi.org/10.1007/s10802-016-0251-8

Khera, M. L. K., Harvey, A. J., \& Callan, M. J. (2014). Beliefs in a just world, subjective wellbeing and attitudes towards refugees among refugee workers. Social Justice Research, 27(4), 432-443. https://doi.org/10.1007/s11211-014-0220-8

Killikelly, C., Bauer, S., \& Maercker, A. (2018). The assessment of grief in refugees and postconflict survivors: a narrative review of etic and emic research. Frontiers in Psychology, 9, 1957.

Kotzur, P. F., Forsbach, N., \& Wagner, U. (2017). Choose your words wisely: Stereotypes, emotions, and action tendencies toward fled people as function of the group label. Social Psychology, 48(4), 226-241. https://doi.org/10.1027/1864-9335/a000312

Krause, U. (2017). Escaping conflicts and being safe? Post-conflict refugee camps and the continuum of violence. In S. Buckley-Zistel \& U. Krause (Eds.), Gender, violence, refugees (pp. 173-196). Oxford, UK: Berghahn.

Kuhlman, T. (1991). The economic integration of refugees in developing countries: A research model. Journal of Refugee Studies, 4(1), 1-20. https://doi.org/10.1093/jrs/4.1.1

Kuo, B. C. H. (2014). Coping, acculturation, and psychological adaptation among migrants: A theoretical and empirical review and synthesis of the literature. Health Psychology and Behavioral Medicine, 2(1), 16-33. https://doi.org/10.1080/21642850.2013.843459

La6izi Community (2019). Audio files. Retrieved from https://soundcloud.com/la6izi Lazarus, R. S., \& Folkman, S. (1984). Stress, appraisal and coping. New York, NY: Springer. 
Lee, J.-S., \& Nerghes, A. (2018). Refugee or migrant crisis? Labels, perceived agency, and sentiment polarity in online discussions. Social Media + Society, 4(3), 1-22. https://doi.org/10.1177/2056305118785638

Li, S. S. Y., Liddell, B. J., \& Nickerson, A. (2016). The relationship between post-migration stress and psychological disorders in refugees and asylum seekers. Current Psychiatry Reports, 18(82), 1-9. https://doi.org/10.1007/s11920-016-0723-0

Liebkind, K. (1996). Acculturation and stress: Vietnamese refugees in Finland. Journal of Cross-Cultural Psychology, 27(2), 161-180. https://doi.org/10.1177\%2F0022022196272002

Liebkind, K., \& Jasinskaja-Lahti, I. (2000). The influence of experiences of discrimination on psychological stress: A comparison of seven immigrant groups. Journal of Community \& Applied Social Psychology, 10(1), 1-16. https://doi.org/10.1002/(SICI)10991298(200001/02)10:1\%3C1::AID-CASP521\%3E3.0.CO;2-5

Ludwig, B. (2016). "Wiping the refugee dust from my feet": Advantages and burdens of refugee status and the refugee label. International Migration, 54(1), 5-18. https://doi.org/10.1111/imig.12111

Lüders, A., Prentice, M., \& Jonas, E. (2019). Refugees in the media: Exploring a vicious cycle of frustrated psychological needs, selective exposure, and hostile intergroup attitudes. European Journal of Social Psychology. Advance online publication. https://doi.org/10.1002/ejsp.2580

Lustig, S. L., Kia-Keating, M., Knight, W. G., Geltman, P., Ellis, H., Kinzie, J. D. . . \& Saxe, G. N. (2004). Review of child and adolescent refugee mental health. Journal of the American Academy of Child \& Adolescent Psychiatry, 43(1), 24-36. https://doi.org/10.1097/00004583-200401000-00012 
Major, B., Quinton, W. J., \& McCoy, S. K. (2002). Antecedents and consequences of attributions to discrimination: Theoretical and empirical advances. In M. P. Zanna (Ed.), Advances in experimental social psychology (Vol. 34, pp. 251-330). San Diego, CA: Academic Press.

Marchi, S. (2005). What is migration without integration? Refugee Survey Quarterly, 24(4), 22-26. https://doi.org/10.1093/rsq/hdi076

Markey, P., Lowmaster, S., \& Eichler, W. (2010). A real-time assessment of interpersonal complementarity. Personal Relationships, 17(1), 13-25. https://doi.org/10.1111/j.14756811.2010.01249.x

Markus, H. R., \& Kitayama, S. (1991). Culture and the self: Implications for cognition, emotion, and motivation. Psychological Review, 98(2), 224-253. https://doi.org/10.1037/0033-295X.98.2.224

Marsella, A. J. (1994). Ethnocultural diversity and international refugees: Challenges for the global community. In A. J. Marsella, T. Bornemann, S. Ekblad, \& J. Orley (Eds.), Amidst peril and pain: The mental health and well-being of the world's refugees (pp. 341-364). Washington, DC: American Psychological Association. https://doi.org/10.1037/10147-018

Marshall, E. A., Butler, K., Roche, T., Cumming, J., \& Taknint, J. T. (2016). Refugee youth: A review of mental health counselling issues and practices. Canadian Psychology/Psychologie Canadienne, 57(4), 308-319. https://doi.org/10.1037/cap0000068

Masgoret, A.-M., \& Ward, C. (2006). The cultural learning approach to acculturation. In D.L. Sam \& J.W. Berry (Eds.), Cambridge handbook of acculturation psychology (pp. 5877). Cambridge, UK: Cambridge University Press. 
McCrae, R. R. (1984). Situational determinants of coping responses: Loss, threat, and challenge. Journal of Personality and Social Psychology, 46(4), 919-928. https://doi.org/10.1037/0022-3514.46.4.919

McCrae, R. R. (1987). Creativity, divergent thinking, and openness to experience. Journal of Personality and Social Psychology, 52(6), 1258-1265. https://doi.org/10.1037/00223514.52.6.1258

McCrae, R. R., \& Costa, P. T. (1997). Personality trait structure as a human universal. American Psychologist, 52(5), 509-516. https://doi.org/10.1037/0003-066X.52.5.509

Mekhennet, S., \& Booth, W. (2015, September 23). Migrants are disguising themselves as Syrians to enter Europe. The Washington Post. Retrieved from http://washingtonpost.com

Mestheneos, E., \& Ioannidi, E. (2002). Obstacles to refugee integration in the European Union member states. Journal of Refugee Studies, 15(3), 304-320. https://doi.org/10.1093/jrs/15.3.304

Miller, K. E., Weine, S. M., Ramic, A., Brkic, A., Bjedic, Z. D., Smajkic, A., Boskailo, E., \& Wortington, G. (2002). The relative contribution of war experiences and exile-related stressors to levels of psychological distress among Bosnian refugees. Journal of Traumatic Stress, 15(5), 377-387. https://doi.org/10.1023/A:1020181124118

Mittal, D., Drummond, K. L., Blevins, D., Curran, G., Corrigan, P., \& Sullivan, G. (2013). Stigma associated with PTSD: Perceptions of treatment seeking combat veterans. Psychiatric Rehabilitation Journal, 36(2), 86-92. https://doi.org/10.1037/h0094976 Moeller, S. D. (1999). Compassion fatigue: How the media sell disease, famine, war and death. New York, NY: Routledge. 
Moore, W. H., \& Shellman, S. M. (2004). Fear of persecution: Forced migration, 1952-1995. Journal of Conflict Resolution, 48(5), 723-745. https://doi.org/10.1177/0022002704267767

Morina, N., Stam, K., Pollet, T. V., \& Priebe, S. (2018). Prevalence of depression and posttraumatic stress disorder in adult civilian survivors of war who stay in war-afflicted regions. A systematic review and meta-analysis of epidemiological studies. Journal of Affective Disorders, 239, 328-338. https://doi.org/10.1016/j.jad.2018.07.027

Morrison, J., \& Crosland, B. (2000). The trafficking and smuggling of refugees: the end game in European asylum policy? Geneva, Switzerland: UNHCR.

Murray, K. E., \& Marx, D. M. (2013). Attitudes toward unauthorized immigrants, authorized immigrants, and refugees. Cultural Diversity and Ethnic Minority Psychology, 19(3), 332-341. https://doi.org/10.1037/a0030812

Neumayer, E. (2005). Bogus refugees? The determinants of asylum migration to Western Europe. International Studies Quarterly, 49(3), 389-410. https://doi.org/10.1111/j.1468-2478.2005.00370.x

Noor, M., Kteily, N., Siem, B., \& Mazziotta, A. (2019). “Terrorist” or “mentally ill”: Motivated biases rooted in partisanship shape attributions about violent actors. Social Psychological and Personality Science, 10(4), 485-493. https://doi.org/10.1177/1948550618764808

Nguyen, A. M. D., \& Benet-Martínez, V. (2013). Biculturalism and adjustment: A metaanalysis. Journal of Cross-Cultural Psychology, 44(1), 122-159. https://doi.org/10.1177/0022022111435097

Odé, A., \& Veenman, J. (2003). The ethno-cultural and socio-economic position of ethnic minority groups in the Netherlands. In L. Hagendoorn J. Veenman, \& W. Vollebergh 
(Eds.), Integrating immigrants in The Netherlands: Cultural versus socio-economic integration (pp. 189-214). New York: Routledge.

Oskarsson, S., Dawes, C., Johannesson, M., \& Magnusson, P. K. (2012). The genetic origins of the relationship between psychological traits and social trust. Twin Research and Human Genetics, 15(1), 21-33. https://doi.org/10.1375/twin.15.1.21

Otto, M., \& Hinton, D. E. (2006). Modifying exposure-based CBT for Cambodian refugees with posttraumatic stress disorder. Cognitive and Behavioral Practice, 13(4), 261-270. https://doi.org/10.1016\%2Fj.cbpra.2006.04.007

Passarlay, G. (2015). The lightless sky: A twelve-year-old refugee's extraordinary journey across half the world. New York, NY: Harper Collins.

Paulhus, D. L., \& Williams, K. M. (2002). The dark triad of personality: Narcissism, Machiavellianism, and psychopathy. Journal of Research in Personality, 36(6), 556563. https://doi.org/10.1016/S0092-6566(02)00505-6

Pettigrew, T. F., \& Tropp, L. R. (2006). A meta-analytic test of intergroup contact theory. Journal of Personality and Social Psychology, 90(5), 751-783. https://doi.org/10.1037/0022-3514.90.5.751

Pettigrew, T. F., Christ, O., Wagner, U., \& Stellmacher, J. (2007). Direct and indirect intergroup contact effects on prejudice: A normative interpretation. International Journal of Intercultural Relations, 31(4), 411-425. https://doi.org/10.1016/j.ijintrel.2006.11.003

Pineteh, E. A. (2017). Moments of suffering, pain and resilience: Somali refugees' memories of home and journeys to exile. Cogent Social Sciences, 3, 1-15. https://doi.org/10.1080/23311886.2017.1372848

Priebe, S., Giacco, D., \& El-Nagib, R. (2016). Public health aspects of mental health among migrants and refugees: A review of the evidence on mental health care for refugees, 
asylum seekers and irregular migrants in the WHO European region. Copenhagen, Denmark: WHO Regional Office for Europe.

Rajaram, P. K. (2002). Humanitarianism and representations of the refugee. Journal of Refugee Studies, 15(3), 247-264. https://doi.org/10.1093/jrs/15.3.247

Reid, S. (2016, May 28). The tragic but brutal truth: They are not REAL refugees! Despite drowning tragedy thousands of economic migrants are still trying to reach Europe. The Daily Mail. Retrieved from https://www.dailymail.co.uk/news/article3613603/The-tragic-brutal-truth-not-REAL-refugees-Despite-drowning-tragedythousands-economic-migrants-trying-reach-Europe.html

Reisel, W. D., Probst, T. M., Chia, S. L., Maloles, C. M., \& König, C. J. (2010). The effects of job insecurity on job satisfaction, organizational citizenship behavior, deviant behavior, and negative emotions of employees. International Studies of Management \& Organization, 40(1), 74-91. https://doi.org/10.2753/IMO0020-8825400105

Renzaho, A. M. N., McCabe, M., \& Sainsbury, W. J. (2011). Parenting, role reversals and the preservation of cultural values among Arabic speaking migrant families in Melbourne, Australia. International Journal of Intercultural Relations, 35(4), 416-424. https://doi.org/10.1016/j.ijintrel.2010.09.001

Riaño-Alcalá, P. (2008). Journeys and landscapes of forced migration: Memorializing fear among refugees and internally displaced Colombians. Social Anthropology, 16(1), 118. https://doi.org/10.1111/j.1469-8676.2008.00036.x

Richmond, A. H. (1993). Reactive migration: Sociological perspectives on refugee movements. Journal of Refugee Studies, 6(1), 7-24. https://doi.org/10.1093/jrs/6.1.7

Rogoff, B., Paradise, R., Mejía Arauz, R., Correa-Chávez, M., \& Angelillo, C. (2003). Firsthand learning through intent participation. Annual Review of Psychology, 54, 175203. https://doi.org/10.1146/annurev.psych.54.101601.145118 
Ross, J. M., Girard, J. M., Wright, A. G. C., Beeney, J. E., Scott, L. N., Hallquist, M. N., ... \& Pilkonis, P. A. (2017). Momentary patterns of covariation between specific affects and interpersonal behavior: Linking relationship science and personality assessment. Psychological Assessment, 29(2), 123-134. https://doi.org/10.1037/pas0000338

Rudmin, F. W. (2003). Critical history of the acculturation psychology of assimilation, separation, integration, and marginalization. Review of General Psychology, 7(1), 3-37. https://doi.org/10.1037/1089-2680.7.1.3

Rudmin, F. W., \& Ahmadzadeh, V. (2001). Psychometric critique of acculturation psychology: The case of Iranian migrants in Norway. Scandinavian Journal of Psychology, 42(1), 41-56. https://doi.org/10.1111/1467-9450.00213

Ryan, D., Dooley, B., Benson, C. (2008). Theoretical perspectives on post-migration adaptation and psychological well-being among refugees: Towards a resource-based model. Journal of Refugee Studies, 21(1), 1-18. https://doi.org/10.1093/jrs/fem047

Sam, D. L., \& Berry, J. W. (2010). Acculturation: When individuals and groups of different cultural backgrounds meet. Perspectives on Psychological Science, 5(4), 472-481. https://doi.org/10.1177/1745691610373075

Schmeidl, S. (1997). Exploring the causes of forced migration: A pooled time-series analysis, 1971-1990. Social Science Quarterly, 78(2), 284-308.

Schmidt, P., \& Weick, S. (2017). Kontakte und die Wahrnehmung von Bedrohungen besonders wichtig für die Einschätzung von Migranten: Einstellungen der deutschen Bevölkerung zu Zuwanderern von 1980 bis 2016 [Contact and threat perception are important for the evaluation of migrants: Attitudes of the German population toward immigrants from 1980 to 2016]. Informationsdienst Soziale Indikatoren [Information Service Social Indicators], 57, 1-7. https://doi.org/10.15464/isi.57.2017.1-7 
Schönwälder, K. (1999). 'Persons persecuted on political grounds shall enjoy the right of asylum - but not in our country': Asylum policy and debates about refugees in the Federal Republic of Germany. In A. Bloch \& C. Levy (Eds.), Refugees, citizenship and social policy in Europe (pp. 76-90). Houndmills, UK: MacMillan.

Schuler, H., Thornton, G. C., III, Frintrup, A., \& Mueller-Hanson, R. (2003). Achievement Motivation Inventory Test Manual. Goettingen, Germany: Hogrefe.

Schweitzer, R., Perkoulidis, S., Krome, S., Ludlow, C., \& Ryan, M. (2005). Attitudes towards refugees: The dark side of prejudice in Australia. Australian Journal of Psychology, 57(3), 170-179. https://doi.org/10.1080/00049530500125199

Schwoerer, C. E., May, D. R., Hollensbe, E. C., \& Mencl, J. (2005). General and specific selfefficacy in the context of a training intervention to enhance performance expectancy. Human Resource Development Quarterly, 16, 111-129. https://doi.org/10.1002/hrdq.1126

Seidle, F. L., \& Joppke, C. (2012). Introduction. In C. Joppke \& F. L. Seidle (Eds.), Immigrant integration in federal countries (pp. 3-21). Montreal, Canada: McGill-Queen's University Press.

Seligman, M. E. (in press). Positive psychology: A personal history. Annual Review of Clinical Psychology.

Shacknove, A. E. (1985). Who is a refugee? Ethics, 95(2), 274-284.

Shelton, J. N., \& Richeson, J. A. (2006). Interracial interactions: A relational approach. Advances in Experimental Social Psychology, 38, 121-181. https://doi.org/10.1016/S0065-2601(06)38003-3

Silove, D., Sinnerbrink, I., Field, A., Manicavasagar, V., \& Steel, Z. (1997). Anxiety, depression and PTSD in asylum-seekers: Associations with pre-migration trauma and 
post-migration stressors. British Journal of Psychiatry, 170(4), 351-357. https://doi.org/10.1192/bjp.170.4.351

Sleijpen, M., Boeije, H. R., Kleber, R. J., \& Mooren, T. (2015). Between power and powerlessness: A meta-ethnography of sources of resilience in young refugees. Ethnicity \& Health, 21(2), 158-180. https://doi.org/10.1080/13557858.2015.1044946

Sleijpen, M., Mooren, T., Kleber, R. J., \& Boeije, H. R. (2017). Lives on hold: A qualitative study of young refugees' resilience strategies. Childhood, 24(3), 348-365. https://doi.org/10.1177/0907568217690031

Smith, E. R., Mackie, D. M., \& Claypool, H. (2014). Social psychology (4th ed.). New York, NY: Psychology Press.

Specht, J., Egloff, B., \& Schmukle, S. C. (2011). The benefits of believing in chance or fate: External locus of control as a protective factor for coping with the death of a spouse. Social Psychological and Personality Science, 2(2), 132-137. https://doi.org/10.1177/1948550610384635

Stephan, C. W., \& Stephan, W. G. (1992). Reducing intercultural anxiety through intercultural contact. International Journal of Intercultural Relations, 16(1), 89-106. https://doi.org/10.1016/0147-1767(92)90007-H

Stephan, W. G., Ybarra, O., \& Bachman, G. (1999). Prejudice toward immigrants. Journal of Applied Social Psychology, 29(11), 2221-2237. https://doi.org/10.1111/j.15591816.1999.tb00107.x

Strang, A., \& Ager, A. (2010). Refugee integration: Emerging trends and remaining agendas. Journal of Refugee Studies, 23(4), 589-607. https://doi.org/10.1093/jrs/feq046

Stürmer, S., \& Siem, B. (2017). A group-level theory of helping and altruism within and across group boundaries. In van E. Leeuwen \& H. Zagefka (Eds.), Intergroup helping (pp. 103-127). New York, NY: Springer. 
Sverke, M., Hellgren, J., \& Näswall, K. (2002). No security: A meta-analysis and review of job insecurity and its consequences. Journal of Occupational Health Psychology, 7(3), 242-264. https://doi.org/10.1037/1076-8998.7.3.242

Tascón, S. M. (2003). Australia's new other: Shaping compassion for onshore refugees. Journal of Australian Studies, 27(77), 5-13. https://doi.org/10.1080/14443050309387846

Taylor, S. E. (1983). Adjustment to threatening events: A theory of cognitive adaptation. American Psychologist, 38(11), 1161-1173. https://doi.org/10.1037/0003066X.38.11.1161

Taylor, S. E. (2002). The tending instinct: How nurturing is essential to who we are and how we live. New York: Holt.

Tedeschi, R. G., Calhoun, L. G. (1996). The posttraumatic growth inventory: Measuring the positive legacy of trauma. Journal of Traumatic Stress, 9(3), 455-471. https://doi.org/10.1007/BF02103658

Turner, J. C., Hogg, M. A., Oakes, P. J., Reicher, S. D., \& Wetherell, M. S. (1987).

Rediscovering the social group: A self-categorization theory. Cambridge, MA: Basil Blackwell.

UNHCR (2018a). UNHCR statistics: The world in numbers. Retrieved from http://popstats.unhcr.org/en/overview

UNHCR (2018b). Report of the United Nations High Commissioner for Refugees: Global compact on refugees. Retrieved from https://www.unhcr.org/gcr/GCR_English.pdf

UNHCR (2018c). UNHCR global trends: Forced displacement in 2017. Retrieved from http://www.unhcr.org/5b27be547.pdf

UNHCR (2019). Refugee facts. Retrieved from https://www.unrefugees.org/refugeefacts/what-is-a-refugee/ 
United Nations General Assembly (2018). Intergovernmental conference to adopt the global compact for safe, orderly and regular migration. Retrieved from https://undocs.org/A/CONF.231/3

Van Hear, N. (1998). New diasporas. London, UK: University College London Press.

Van Zalk, M. H. W., Nestler, S., Geukes, K., Hutteman, R., \& Back, M. D. (2019). The codevelopment of extraversion and friendships: Bonding and behavioral mechanisms in friendship networks. Journal of Personality and Social Psychology. Advance online publication. https://doi.org/10.1037/pspp0000253

Verkuyten, M. (2004). Emotional reactions to and support for immigrant policies: Attributed responsibilities to categories of asylum seekers. Social Justice Research, 17(3), 293314. https://doi.org/10.1023/B:SORE.0000041295.83611.dc

Verkuyten, M. (2005). Immigration discourses and their impact on multiculturalism: A discursive and experimental study. British Journal of Social Psychology, 44(2), 223240. https://doi.org/10.1348/014466604X23482

Verkuyten, M., Mepham, K., \& Kros, M. (2018). Public attitudes towards support for migrants: The importance of perceived voluntary and involuntary migration. Ethnic and Racial Studies, 41(5), 901-918. https://doi.org/10.1080/01419870.2017.1367021

Voci, A., \& Hewstone, M. (2003). Intergroup contact and prejudice toward immigrants in Italy: The mediational role of anxiety and the moderational role of group salience. Group Processes and Intergroup Relations, 6(1), 37-54. https://doi.org/10.1177\%2F1368430203006001011

Vrecer, N. (2000). Human costs of temporary refugee protection: The case of Slovenia. In A. Rubeli \& N. Vucenic (Eds.), A captured moment in time: IWM junior visiting fellows conferences, 10, 1-21. Vienna, Austria: IWM. 
Wagnild, G., \& Young, H. (1993). Development and psychometric evaluation of the Resilience Scale. Journal of Nursing Measurement, 1(2), 165-178.

Ward, C., Bochner, S., \& Furnham, A. (2001). The psychology of culture shock. Hove, UK: Routledge.

Ward, C., Gale, J., Staerklé, S., \& Stuart, J. (2018). Immigration and multiculturalism in context: A framework for psychological research. Journal of Social Issues, 74(4), 833855. https://doi.org/10.1111/josi.12301

Ward, C., \& Geeraert, N. (2016). Advancing acculturation theory and research: The acculturation process in its ecological context. Current Opinion in Psychology, 8, 98104. https://doi.org/10.1016/j.copsyc.2015.09.021

Ward, C., \& Masgoret, A.-M. (2006). An integrative model of attitudes toward immigrants. International Journal of Intercultural Relations, 30(6), 671-682. https://doi.org/10.1016/j.ijintrel.2006.06.002

Ward, C., Szabo, A., \& Stuart, J. (2016). Prejudice against immigrants in multicultural societies. In C. Sibley \& F. K. Barlow (Eds.), The Cambridge handbook of the psychology of prejudice (pp. 413-437). Cambridge, UK: Cambridge University Press.

Webster, D. M., \& Kruglanski, A. W. (1994). Individual differences in need for cognitive closure. Journal of Personality and Social Psychology, 67(6), 1049-1062. https://doi.org/10.1037/0022-3514.67.6.1049

Wehrle, K., Kira, M., \& Klehe, U.-C. (2019). Putting career construction into context: Career adaptability among refugees. Journal of Vocational Behavior, 111, 107-124. https://doi.org/10.1016/j.jvb.2018.08.007

Wehrle, K., Klehe, U.-C., Kira, M., \& Zikic. J. (2018). Can I come as I am? Refugees' vocational identity threats, coping, and growth. Journal of Vocational Behavior, 105, 83-101. https//doi.org/10.1016/j.jvb.2017.10.010 
Weiner, B. (2000). Intrapersonal and interpersonal theories of motivation from an attributional perspective. Educational Psychology Review, 12(1), 1-14. https://doi.org/10.1023/A:1009017532121

Wiggins, J. S. (1991). Agency and communion as conceptual coordinates for the understanding and measurement of interpersonal behavior. In D. Cicchetti \& W. M. Grove (Eds.), Thinking clearly about psychology: Essays in honor of Paul E. Meehl, Vol. 2: Personality and psychopathology (pp. 89-113). Minneapolis, MN: University of Minnesota Press.

Wike, R., Stokes, B., \& Simmons, K. (2016). Europeans fear wave of refugees will mean more terrorism, fewer jobs. Pew Research Center. Retrieved from http://www.pewglobal.org/wp-content/uploads/sites/2/2016/07/Pew-Research-CenterEU-Refugees-and-National-Identity-Report-FINAL-July-11-2016.pdf

Wrzus, C., \& Mehl, M. R. (2015). Lab and/or field? Measuring personality processes and their social consequences. European Journal of Personality, 29(2), 250-271. https://doi.org/10.1002/per.1986

Yakushko, O. (2010). Stress and coping strategies in the lives of recent immigrants: A grounded theory model. International Journal for the Advancement of Counselling, 32(4), 256-273. https://doi.org/10.1007/s10447-010-9105-1

Yakushko, O., Watson, M., \& Thompson, S. (2008). Stress and coping in the lives of recent immigrants and refugees: Considerations for counseling. International Journal for the Advancement of Counselling, 30(3), 167-178. https://doi.org/10.1007/s10447-0089054-0

Zacher, H., \& Frese, M. (2009). Remaining time and opportunities at work: Relationships between age, work characteristics, and occupational future time perspectives. Psychology and Aging, 24(2), 487-493. https://doi.org/10.1037/a0015425 
Zagefka, H., \& Brown, R. (2002). The relationship between acculturation strategies, relative fit and intergroup relations: Immigrant-majority relations in Germany. European Journal of Social Psychology, 32(2), 171-188. https://doi.org/10.1002/ejsp.73

Zetter, R. (1991). Labelling refugees: Forming and transforming a bureaucratic identity. Journal of Refugee Studies, 4(1), 39-62. https://doi.org/10.1093/jrs/4.1.39

Zetter, R. (2007). More labels, fewer refugees: Remaking the refugee label in an era of globalization. Journal of Refugee Studies, 20(2), 172-192. https://doi.org/10.1093/jrs/fem011

Zimmerman, B. J. (2000). Self-efficacy: An essential motive to learn. Contemporary Educational Psychology, 25(1), 82-91. https://doi.org/10.1006/ceps.1999.1016 
Figure Caption

Figure 1. Psychological Antecedents of Refugee Integration (PARI): Depiction of the model with a focus on characteristic features of refugee migration (refugees' and residents' perceptions of forcedness and related perils) 


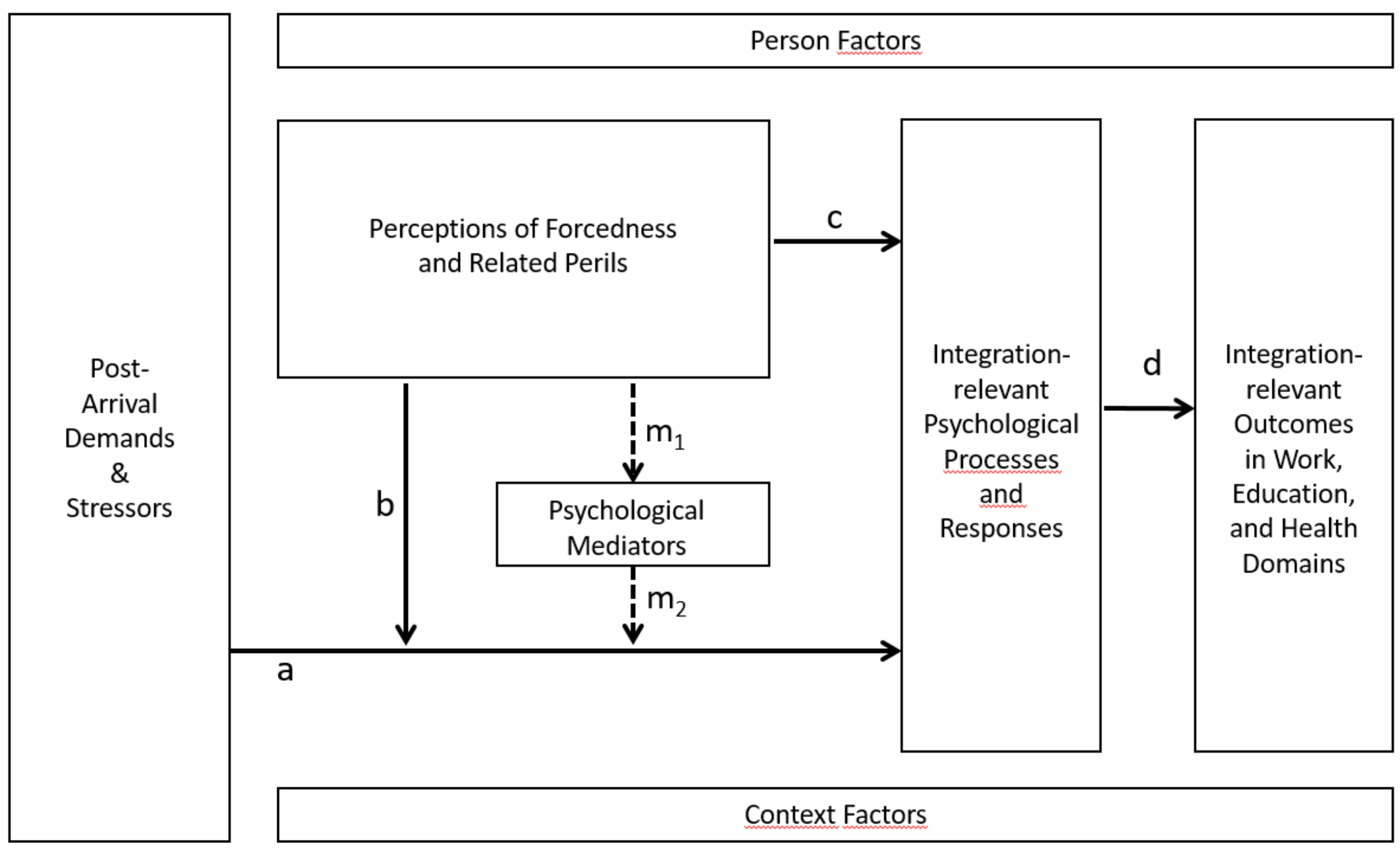

Figure 1. 